\title{
Detection, Distribution, and Genetic Variability of 'Candidatus Liberibacter' Species Associated with Zebra Complex Disease of Potato in North America
}

\author{
A. Wen and I. Mallik, Department of Plant Pathology, North Dakota State University, Fargo, ND 58108; V. Y. Alvarado, \\ Department of Plant Pathology and Microbiology, Texas AgriLife, Texas A\&M University, College Station, TX \\ 77843; J. S. Pasche and X. Wang, Department of Plant Pathology, North Dakota State University, Fargo, ND 58108; \\ W. Li and L. Levy, USDA-APHIS-PPQ-CPHST, Beltsville, MD, 20705; H. Lin, USDA-ARS, 9611 S. Riverbend \\ Avenue, Parlier, CA 93648; H. B. Scholthof, Department of Plant Pathology and Microbiology, Texas AgriLife, \\ Texas A\&M University, College Station, TX 77843; T. E. Mirkov, Department of Plant Pathology and Microbiology, \\ Texas AgriLife, Texas A\&M University, Weslaco, TX 78596; C. M. Rush, Department of Plant Pathology and Mi- \\ crobiology, Texas AgriLife, Texas A\&M University, Bushland, TX 79012; and N. C. Gudmestad, Department of \\ Plant Pathology, North Dakota State University, Fargo, ND 58108
}

\begin{abstract}
Wen, A., Mallik, I., Alvarado, V. Y., Pasche, J. S., Wang, X., Li, W., Levy, L., Lin, H., Scholthof, H. B., Mirkov, T. E., Rush, C. M., and Gudmestad, N. C. 2009. Detection, distribution, and genetic variability of 'Candidatus Liberibacter' species associated with zebra complex disease of potato in North America. Plant Dis. 93:1102-1115.
\end{abstract}

The specificity and sensitivity of polymerase chain reaction (PCR) primers developed for 'Candidatus Liberibacter solanacearum' and 'Candidatus Liberibacter psyllaurous' were evaluated in conventional and real-time PCR assays. All PCR primers were specific for ' $\mathrm{Ca}$. L. psyllaurous' and ' $\mathrm{Ca}$. L. solanacearum' insomuch as they did not detect other prokaryotic plant pathogens that affect potato except for the putative pathogens associated with psyllid-yellows and haywire. Conventional PCR assays were capable of detecting 0.19 to $1.56 \mathrm{ng}$ of total DNA per reaction, and real-time PCR was found capable of detecting 1.56 to $6.25 \mathrm{ng}$ of total DNA per reaction, depending on the specific PCR primer set used. 'Ca. Liberibacter' species associated with zebra complex disease (ZC) was confirmed in plants affected by this disease throughout Texas from 2005 to 2008, in seed tubers produced in Wyoming in 2007, and in Colorado, Kansas, Nebraska, and Mexico in 2008. A multiplex PCR assay using ' $\mathrm{Ca}$. L. solanacearum'-specific primers and primers specific for the $\beta$-tubulin DNA regions from potato was developed, providing possible utility of the multiplex assay for ' $\mathrm{Ca}$. Liberibacter' detection in different solanaceous plant species. Preliminary studies suggest silverleaf nightshade (Solanum elaeagnifolium), wolfberry (Lycium barbarum), black nightshade (S. ptychanthum), and jalapeno pepper (Capsicum annиum) as additional solanaceous hosts for the $\mathrm{ZC}$-associated bacterium. The ' $\mathrm{Ca}$. Liberibacter' species detected in all samples divided into two clusters sharing similarity of $99.8 \%$ in their partial 16S rRNA gene sequences and $99.3 \%$ in their partial intergenic spacer region (ISR)-23S rRNA gene sequences. Genetic variation in the $16 \mathrm{~S}$ rDNA region consistently matched that of the ISR-23S rDNA region. In this partial 16S-ISR-23S rDNA region, there was a total of eight single nucleotide polymorphisms among ' $\mathrm{Ca}$. L. psyllaurous' and ' $\mathrm{C} a$. L. solanacearum' "strains" investigated in this study. ' $C a$. L. solanacearum' and ' $C a$. L. psyllaurous' were shown to be very closely related bacteria, if not the same, by successful amplification using a combination of forward primer of ' $\mathrm{Ca}$. L. solanacearum' and reverse primer of ' $\mathrm{Ca}$. L. psyllaurous' in ZC-affected potato samples. This finding clarifies the current taxonomic status of ' $\mathrm{Ca}$. L. solanacearum' and ' $\mathrm{Ca}$. L. psyllaurous'. The detection of ' $\mathrm{Ca}$. L. solanacearum' from haywire-symptomatic potato samples demonstrates that this bacterium might also be associated with this disease.

Zebra chip (ZC) is a recently recognized disease of potato characterized by symptoms that include necrotic flecking and medullary ray discoloration in afflicted tubers. Foliar symptoms of $\mathrm{ZC}$ include

Corresponding author: Neil Gudmestad

E-mail: Neil.Gudmestad@ndsu.edu

GenBank accession nos. FJ829800-FJ829815 and FJ830690-FJ830706 derived from this study.

Accepted for publication 16 July 2009.

doi:10.1094/PDIS-93-11-1102

(c) 2009 The American Phytopathological Society disease" (also commonly abbreviated ZC).

Given the resemblance of tuber symptomatology of net necrosis to $\mathrm{ZC}$, phloemrestricted pathogens have been the focal point of studies to determine the cause of this disease. The pathogen first associated with ZC was identified as a phytoplasma (33), which was subsequently named 'Candidatus Phytoplasma americanum' (16). This phytoplasma was determined to be closely related to the stolbur phytoplasma, which has been reported to be the cause of a potato tuber disease in Eastern Europe $(24,25)$. Although ' $\mathrm{Ca}$. P. americanum' was the primary pathogen associated with ZC in Nebraska, it has never been consistently associated with ZC in Texas (N. C. Gudmestad, unpublished). More recently, 'Candidatus Liberibacter solanacearum', an $\alpha$-proteobacterium bacterial-like organism (BLO), was found to be associated with $\mathrm{ZC}$ in potato in New Zealand $(20,22)$ and the cause of a similar disease in other solanaceous hosts $(19,21)$. In the United States, another $\alpha$ proteobacterium with $99.95 \%$ similarity in its 16S rRNA gene sequence to ' $C a$. L. solanacearum' has been associated with psyllid-yellows (PY) disease of potato and has been named 'Candidatus Liberibacter psyllaurous' (11). The symptomatology of PY differs significantly from that of ZC. Foliar symptoms of PY include pronounced yellowing of the foliage and shortening of the internodes, resulting in a dwarf rosette appearance (4) (Fig. 1D). The tuber necrosis symptoms characteristic of $\mathrm{ZC}$ are absent in tubers produced from plants with PY, but PY-affected tubers occasionally demonstrate a slight vascular discoloration (Fig. 1E). Perhaps more importantly, ZC is a lethal condition of potato plants, whereas PY is only rarely lethal, and in some instances plants recover and return to a healthy condition (N. C. Gudmestad, unpublished). Interestingly, both ' $\mathrm{Ca}$. L. solanacearum' and ' $C a$. L. psyllaurous' recently have been associated with ZC of potato in California (5), Texas (1,34), Guatemala (34), and 
Mexico (31,34). Haywire (HW) (Fig. 1F) is a disease of potato that has been associated with secondary infections (seedborne) of ' $\mathrm{Ca}$. Phytoplasma' species, particularly aster yellows (35). We also have observed that plants with HW symptoms can arise from seed tubers with symptoms characteristic of ZC. Previously, ' $C a$. Liberibacter' species have only been associated with Citrus sp. and other members of the Rutaceae $(3,40)$. ' $C a$. L. psyllaurous' and ' $C a$. L. solanacearum' are closely related to the three species of ' $\mathrm{Ca}$. Liberibacter' known to be associated with huanglongbing (HLB) of citrus $(11,20,22)$. Based on the results of studies reported here, ' $\mathrm{Ca}$. L. psyllaurous' and ' $\mathrm{Ca}$. L. solanacearum' will be referred to as ' $\mathrm{Ca}$. L. solanacearum' throughout this manuscript.
Although ZC has been known to occur in the United States and Mexico for some time, a survey for the disease and its causal organisms has not been conducted. Additionally, while a number of primer sets have been developed for the detection of ' $C a$. L. solanacearum' using polymerase chain reaction (PCR) $(11,20)$, these primers have not been compared for sensitivity and efficiency of detection. Furthermore,
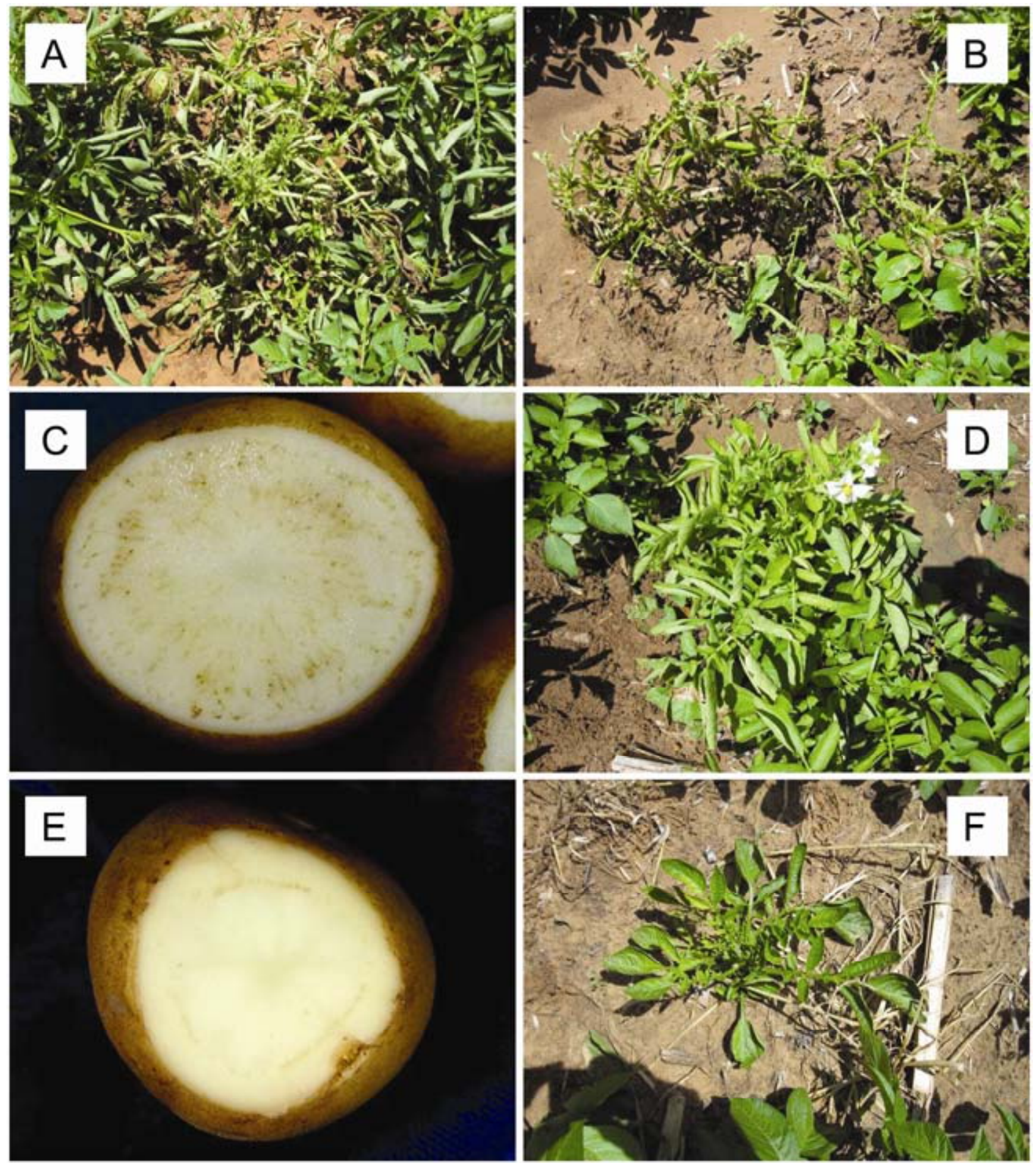

Fig. 1. Photographs depicting potato plants with diseases associated with 'Candidatus Liberibacter solanacearum' and 'Ca. L. psyllaurous'. A, Initial foliar zebra complex disease (ZC) symptoms associated with ' $\mathrm{Ca}$. L. solanacearum'; B, advanced foliar ZC symptoms associated with 'Ca. L. solanacearum'; $\mathbf{C}$, tuber ZC symptoms associated with 'Ca. L. solanacearum'; D, foliar psyllid-yellows (PY) symptoms associated with 'Ca. L. psyllaurous'; E, tuber PY symptoms with mild necrosis of the vascular ring; and F, foliar haywire symptoms. Note leaf scorching of potato plants with ZC (A and B), generally leading to plant death. Plants with PY are chlorotic with dwarf rosette appearance (D) but are less debilitated. Plants depicted in A, B, and D were found in the same field near Pearsall, TX within $3 \mathrm{~m}$ of each other. 
very little information exists on the specificity of these primers in detecting ' $\mathrm{Ca}$. L. psyllaurous' and ' $C a$. L. solanacearum' relative to other prokaryotic pathogens that infect potato. Therefore, the specific objectives of these studies were to (i) compare and determine the sensitivity and specificity of conventional and real-time PCR assays for the detection of ' $\mathrm{Ca}$. L. solanacearum'; (ii) determine spatial and temporal distribution of ' $\mathrm{Ca}$. L. solanacearum' in Texas using archived DNA samples obtained from ZC-affected potato plants in 2005 to 2007; (iii) confirm the presence of ' $C a$. L. solanacearum' in ZC-, PY-, and $\mathrm{HW}$-affected samples collected from the midwestern United States and Mexico in 2008; (iv) develop multiplex PCR assays for the detection of ' $\mathrm{Ca}$. L. solanacearum' for future use in solanaceous hosts; and (v) assess the genetic variability of " $\mathrm{Ca}$. L. solanacearum' "strains" obtained from ZC-, HW-, and PY-symptomatic potato plants.

\section{MATERIALS AND METHODS}

Plant material and DNA extraction. ZC symptomatic potato plants were collected from near McAllen, Pearsall, Kermit, Olton, and Dalhart, TX from 2005 to 2007. The majority were collected by one of the authors (N. C. Gudmestad). These locations represent all commercial potato production regions of the state and span approximately 800 miles from McAllen in the lower Rio Grande Valley to Dalhart in the northern Panhandle. Five hundred milligrams of leaf, petiole, midvein, aboveground stem, stolon, and tuber tissue was ground in liquid nitrogen with a mortar and pestle, and DNA extraction was performed using DNeasy Plant Mini Kit (Qiagen, Valencia, CA). The DNA samples from $\mathrm{ZC}$-affected plants were archived at $-80^{\circ} \mathrm{C}$, in some cases for several years, until they could be used in the investigations described below.

Plants with characteristic symptoms of $\mathrm{ZC}$, including tuber symptoms, were collected from potato fields in Texas, $\mathrm{Ne}$ braska, Colorado, and Kansas in 2008 and shipped on ice to Dr. Gudmestad's lab at NDSU for processing. Thirty ZC symptomatic potato plants and nine tubers were collected from Mexican commercial potato fields (USDA APHIS permit: PDEP-0700193). In addition, potato plants with symptoms of HW disease were collected from one location in Nebraska in 2008, one in Florida in 2005, two in Minnesota in 2005 and 2007, and two in Texas in 2008. Interestingly, the HW plants collected from Texas were grown from seed tubers that exhibited symptoms characteristic of ZC, which originated from a certified seed potato lot produced in Wyoming in 2007. DNA was extracted from aboveground stem, stolon, and tuber tissues from all samples as described above.

Potato plants with aboveground symptoms of PY were collected in 2008 from potato fields in Nebraska, Texas, and Kansas. Tomato and jalapeno pepper plants collected from a home garden near Dalhart, TX with a high infestation of potato psyllids were also sampled and processed as described above. Since ' $\mathrm{Ca}$. Phytoplasma' species have been reported to be associated with ZC, PY, and $\mathrm{HW}$ in potato in the United States (33), all the ZC-, $\mathrm{PY}-$, and $\mathrm{HW}$-affected potato samples were initially tested for ' $\mathrm{Ca}$. Phytoplasma' in a nested PCR assay (7) using universal primers as described previously $(8,26,32)$.
Conventional PCR assays. Conventional PCR (cPCR) assays were carried out simultaneously using three sets of primers, $\mathrm{ZCf} / \mathrm{OI} 2 \mathrm{c}, \mathrm{OA} 2 / \mathrm{OI} 2 \mathrm{c}$ (20), and LpFrag41611F/480R (11). ZC-specific forward primer ZCf, 5'-CGAGCGCTTATTTTT ATTAGGAGC- $3^{\prime}$ was designed at the signature region of the $16 \mathrm{~S}$ rDNA sequence of ' $\mathrm{Ca}$. Liberibacter solanacearum' (NCBI GenBank accession no. EU980389). PCR assays were performed in a $25-\mu \mathrm{l}$ reaction consisting of $1 \times$ PCR buffer, $2.5 \mathrm{mM}$ $\mathrm{MgCl}_{2}, 0.2 \mathrm{mM}$ dNTPs, $0.2 \mu \mathrm{M}$ of primer ZCf and OI2c (14), $1 \mathrm{U}$ of Platinum Taq DNA polymerase (Invitrogen, Carlsbad, CA), and $2 \mu$ of DNA. PCR amplification consisted of 1 cycle at $94^{\circ} \mathrm{C}$ for $2 \mathrm{~min}$, followed by 35 cycles of $94^{\circ} \mathrm{C}$ for $30 \mathrm{~s}$, $62^{\circ} \mathrm{C}$ for $30 \mathrm{~s}$, and $72^{\circ} \mathrm{C}$ for $1 \mathrm{~min}$, and extension with 1 cycle of $72^{\circ} \mathrm{C}$ for $10 \mathrm{~min}$. PCR conditions for $\mathrm{OA} 2 / \mathrm{OI} 2 \mathrm{c}$ and $\mathrm{Lp}$ Frag4-1161F/480R were as previously described $(10,11,20)$. PCR amplifications were performed using a DNA Engine (BioRad, Hercules, CA). The sizes of the amplicons are 1,171, 1,168, and $948 \mathrm{bp}$ for primer sets ZCf/OI2c, OA2/OI2c, and Lp Frag4-1611F/480R, respectively (Fig. 2). The identity of ' $C a$. L. psyllaurous' and ' $\mathrm{Ca}$. L. solanacearum' was confirmed by sequencing amplicons from numerous samples, and these sequences were subjected to phylogenetic analysis as described below.

Real-time PCR assays. All three realtime PCR assays were performed using a Stratagene MX3005 thermocycler (Stratagene, La Jolla, CA). The first set of realtime PCR assays utilized ZCf primer, the liberibacter-universal TaqMan probe HLBp, and reverse primer HLBr (14), and cytochrome oxidase of the host plant

\section{L. asiaticus strain psy62 sup. contig (NZ ABQW01000011)

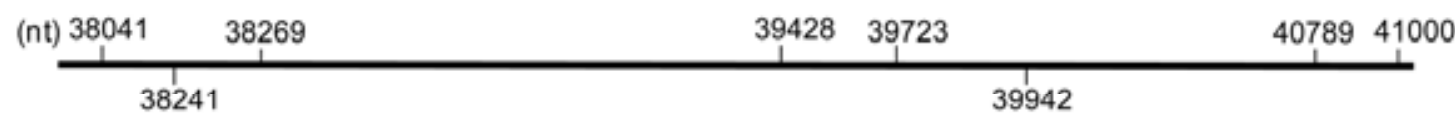

EU980389

(Li et al. 2008*)

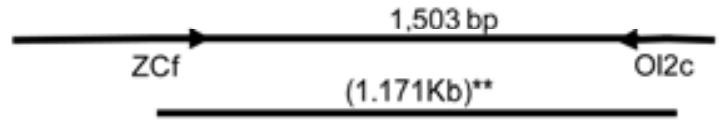

EU935004

(Liefting et al. 2008*)

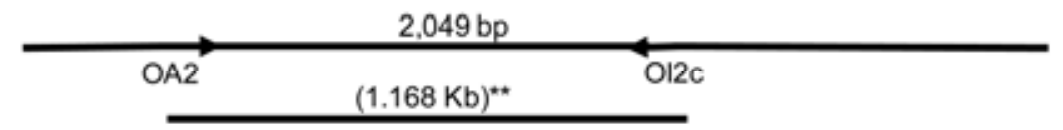

EU812559

(Hansen etal. 2008*)

$2,515 \mathrm{bp}$

*GenBank submission date

()$^{* *}$ : expected size of PCR product

Fig. 2. Relative locations of conventional polymerase chain reaction primers in the 16S-ISR-23S rRNA gene region used in this study. 
(COX-F/COX-R/COX-P) as internal positive control (18). The real-time PCR reaction components and conditions were as described by $\mathrm{Li}$ et al. (17). Real-time primers and probe, LpsF/LpsR/LpsP, were designed based on the 16S-ISR-23S rDNA region of ' $C a$. L. psyllaurous' (EU 812557) for this study. The sequences for the primers and probe are LpsF 5'GAGCGATAAGCTCAAGAAAAGAA-3', Lps-R 5'-CTCAAATGACCCCATCAA CC-3', and LpsP FAM-AAGTTCTAA GGGATCGCCGT-BHQ1. The corresponding real-time PCR assay was performed in a $25-\mu l$ reaction mix consisting of $0.8 \mu \mathrm{M}$ of each primer, $0.4 \mu \mathrm{M}$ of the probe along with $1 \times$ PCR buffer, $6 \mathrm{mM}$ $\mathrm{MgCl}_{2}, 0.12 \mathrm{mM}$ dNTP, 1 U Platinum Taq DNA polymerase, and $2 \mu \mathrm{l}$ DNA. The amplification conditions were 1 cycle at $95^{\circ} \mathrm{C}$ for $5 \mathrm{~min}$, followed by 40 cycles of $95^{\circ} \mathrm{C}$ for $1 \mathrm{~s}, 58^{\circ} \mathrm{C}$ for $40 \mathrm{~s}$, and $72^{\circ} \mathrm{C}$ for $2 \mathrm{~s}$. A third real-time PCR assay using CL-ZC forward and reverse primers (CL-ZCF/CL-ZC-R) (H. Lin, unpublished) was performed using SYBR Green QPCR master mix (Stratagene) following the manufacturer's protocol. For all three real-time PCR assays for ' $C a$. L. solanacearum', a crossing threshold $(\mathrm{Ct})$ of $\leq 35$ cycles was used to determine if a sample was positive.

Multiplex PCR assays. DNA quality was verified by reliable amplification of a potato $\beta$-tubulin (Btub) DNA region with two specific primer sets, Btub1F/R and Btub2 F/R. A 2-kb amplicon resulted from healthy potato DNA samples using primers initially designed to detect $\beta$-tubulin cDNA based on potato transcriptome analysis (41). This amplicon was cloned into pGEM-T Easy vector (Promega, Madison, WI) and then sequenced using Big Dye terminator (Applied Biosystems, Foster City, CA) on an ABI 3100 automated sequencer. Based on this sequence, new $\beta$ tubulin primers with similar annealing temperatures as the ' $\mathrm{Ca}$. Liberibacter'specific primer were designed. The sequences of the primers are: Btub1F 5'-TGATTTCCAAGGTAAGGGAGGA-3', Btub1R 5'-CATGTTGCTCTCGGCTTC AG-3', Btub2F 5'-TGCCACTCACTTGGT GGAGGG-3', and Btub2R 5'-TCATGT TGCTCTCGCTTCAGTG-3'. Amplicon sizes were 881 and 928 bp for Btub1F/R and Btub2F/R, respectively. Multiplex PCR assays were optimized using Btub1F/ $\mathrm{R}$ plus ZCf/OI2c or Btub2F/R plus OA2/ $\mathrm{OI} 2 \mathrm{c}$ with different primer ratios under $\mathrm{ZCf} / \mathrm{OI} 2 \mathrm{c}$ or $\mathrm{OA} 2 / \mathrm{OI} 2 \mathrm{c}$ respective conditions (20) using either Platinum Taq polymerase (Invitrogen) or Phusion DNA polymerase (Espoo, Finland). Btub1F-R primers were evaluated for their specificity and utility on solanaceous species including Capsicum annuum L., Solanum tuberosum L., S. lycopersicum L., Nicotiana benthamiana Domin. (wild type and 16C GFP-transgenic), N. tabacum L. (Glurk and Turk varieties), and N. sylvestris. PCR was performed with $0.4 \mu \mathrm{M}$ of Btub1 $\mathrm{F}$ and $\mathrm{R}$, and the PCR cycle consisted of $94^{\circ} \mathrm{C}$ for $2 \mathrm{~min}, 35$ cycles of $94^{\circ} \mathrm{C}$ for $30 \mathrm{~s}$, $62^{\circ} \mathrm{C}$ for $30 \mathrm{~s}$, and $72^{\circ} \mathrm{C}$ for $2 \mathrm{~min}$, followed by $72^{\circ} \mathrm{C}$ for $10 \mathrm{~min}$.

Specificity of conventional and realtime PCR assays. DNA preparations from plant samples infected with phytoplasmas and related ' $\mathrm{Ca}$. Liberibacter' sp., and from pure bacterial cultures were used to test specificity of all PCR primers (Table 1). A ' $\mathrm{Ca}$. L. solanacearum' PCR positive control DNA sample extracted from infected tomato (S. lycopersicum) and collected from Auckland on 29 April 2008 was kindly provided by Lia Liefting (MAF Biosecurity New Zealand, Auckland, NZ). This ' $C a$. L. solanacearum' DNA sample was initially used to optimize PCR conditions and establish our own positive control DNA for ZC-affected potato sample testing. DNA samples of ' $\mathrm{Ca}$. Liberibacter africanus', ' $\mathrm{Ca}$. Liberibacter americanus', and ' $\mathrm{Ca}$. Liberibacter asiaticus' were obtained from different sources (Table 1). One set of ' $C a$. L. africanus' and ' $C a$. L. americanus' DNA samples, prepared from infected greenhouse periwinkle plants, was provided by Sandrine Eveillard (INRA, Bordeaux, France); two batches of ' $\mathrm{Ca}$. L. asiaticus' DNA samples were prepared in December 2008 and May 2009 from an HLB-symptomatic sweet orange tree (Citrus sinensis) in the field in Florida; a ' $\mathrm{Ca}$. L. africanus' DNA sample was obtained from infected greenhouse periwinkle plants; and another ' $\mathrm{Ca}$. L. asiaticus' DNA sample was provided by Nian Wang (Citrus Research and Education Center, University of Florida, Lake Alfred). The specificity of the conventional and real-time PCR primers also was evaluated using DNA preparations from potato plants with PY symptoms collected from Olton, TX, Dalhart, TX, Kearney, NE, and Garden City, KS in 2008 as well as DNA preparations from HW samples collected from Florida in 2005, Minnesota in 2005 and 2007, and Nebraska in 2008. DNA samples from a healthy potato plant, healthy citrus leaves, and a healthy periwinkle (Catharanthus roseus (L.) G. Don) plant were used as controls in addition to PCR grade water. All DNA extractions and PCR amplifications were carried out as described previously, and all PCR reactions were performed three times.

Sensitivity of conventional and realtime PCR assays. Sensitivity of conventional and real-time PCR assays was determined using DNA extracted from four ZC symptomatic potato plants: ZC06TX342, ZC06TX36-2, ZC06TX49-3, and ZC08MX211. Two-fold serial dilutions were made from a $100-n g / \mu l$ stock DNA sample in water. PCR amplifications were carried out under conditions as described previously and were performed twice.

Detection of ' $\mathrm{Ca}$. L. solanacearum' in ZC symptomatic potato samples using conventional, multiplex, and real-time PCR assays. Detection efficiency was measured by calculating a percentage of ' $\mathrm{Ca}$. L. solanacearum'-positive samples. Overall PCR assay efficiency was calculated for sample testing regardless of geographic location, collection date of the plant samples, and the plant tissue from which the DNA was extracted, as discussed below. A total of 503 ZC-affected potato plants collected between 2005 and 2008 from various locations in Colorado, Florida, Kansas, Nebraska, Texas, and Mexico were evaluated using primers ZCf/OI2c, OA2/OI2c (20), and LpFrag4$1611 F / 480 R$ (11) in a conventional format. Selected amplicons were sequenced to confirm homology to ' $\mathrm{Ca}$. L. solanacearum', and the sequencing data were used for phylogenetic tree construction. ' $\mathrm{Ca}$. L. solanacearum' in planta distribution also was investigated using the three conventional PCR assays and the $\mathrm{ZCf} / \mathrm{HLBr} /$ HLBp real-time PCR assay. Detection frequency of ' $\mathrm{Ca}$. L. solanacearum' from leaf, midvein, petiole, stem, and stolon tissues obtained from 12 ZC-affected potato plants was compared. ' $\mathrm{Ca}$. L. solanacearum' detection using multiplex PCR assays with primers $\mathrm{ZCf} / \mathrm{OI} 2 \mathrm{c} / \mathrm{Btub} 1 \mathrm{~F} / \mathrm{R}$ and $\mathrm{OA} 2 / \mathrm{OI} 2 \mathrm{c} / \mathrm{Btub} 2 \mathrm{~F} / \mathrm{R}$ was evaluated using a total of $594 \mathrm{ZC}$ potato samples collected in commercial fields in Colorado, Florida, Kansas, Nebraska, Texas, and Mexico from 2005 to 2008.

Detection of ' $\mathrm{Ca}$. L. solanacearum' in plant hosts and psyllids using conventional and real-time PCR assays. From 2006 to 2008, samples of several weed species including silverleaf nightshade (Solanum elaeagnifolium Cav.), wolfberry (Lycium barbarum L.), and black nightshade ( $S$. ptychanthum Dun.) were collected in Dalhart, TX. In 2008, tomato plants (S. lycopersicum L.) with foliar symptoms consistent with ZC and infested with psyllids, and healthy jalapeno pepper plants (Capsicum annuum L.) infested with psyllids from a home garden were collected to test for infection by ' $\mathrm{Ca}$. L. solanacearum'. DNA was extracted from petiole, stem, taproot, and primary roots, and detection of ' $\mathrm{Ca}$. L. solanacearum' was done using conventional and realtime PCR assays as described above. Selected amplicons were sequenced to confirm homology to ' $\mathrm{Ca}$. L. solanacearum', and sequencing data were also used in phylogenetic tree construction. Psyllid nymphs and adults were collected from potato, tomato, and jalapeno pepper leaves in Dalhart and Olton, TX and Mexico in 2005 and 2008. All psyllid adults and nymphs were immediately placed into $70 \%$ ethanol after capture and stored in this solution until processed. DNA extraction from single adults or nymphs was carried out using QIAamp DNA Mini Kit (Qiagen). DNA was obtained from 264 psyllid samples, including 96 adults 
collected near Dalhart in 2005, 93 adults collected near Olton on 6 August 2008, 29 adults collected near Olton on $7 \mathrm{Au}-$ gust 2008, 19 adults collected in state of Chihuahua, Mexico on 13 August 2008, 24 samples from third- to fifth-instar nymphs, and 3 one- to two-instar nymphs collected near Dalhart. The presence of ' $\mathrm{Ca}$. L. solanacearum' in psyllid samples was determined using multiplex real-time PCR assays using the LsoF primer and the liberibacter-universal TaqMan probe HLBp and reverse primer HLBr multiplexed with a COX gene internal positive control (17). Twenty-eight DNA extracts (group I) obtained from the psyllids collected on 7 August 2008 in Olton, all 19 DNA extracts (group II) obtained from Mexican psyllids, and 14 DNA extracts (group III) from nymphs were chosen for additional assays. In addition, 61 selected DNA extracts were tested by real-time PCR (9) for the presence of ' $\mathrm{Ca}$. P. americanus' (16), Arsenophonus sp., Myc-symbiont, Syn-symbiont, and Wolbachia sp. (38). All aforementioned conventional and real-time PCR assays were performed twice.
Genetic variation among ' $\mathrm{Ca}$. L. solanacearum' detected from potato samples. Genetic variation within ' $\mathrm{Ca}$. L. solanacearum' was investigated on DNA samples selected from the spatial and temporal surveys to represent all locations and all years in which ' $\mathrm{Ca}$. L. solanacearum' was confirmed using cPCR primers ZCf/OI2c and LpFrag4 1161F/480R (11). Although DNA was prepared primarily from ZC-affected potato plants, DNA from potato plants affected by PY and HW was also included. Thirty-nine ' $\mathrm{Ca}$. L. solanacearum' positive samples were amplified

Table 1. Specificity of conventional and real-time polymerase chain reaction (PCR) assays used for the detection of 'Candidatus Liberibacter psyllaurous' and 'Ca. L. solanacearum'

\begin{tabular}{|c|c|c|c|c|c|c|c|c|c|c|}
\hline \multirow{2}{*}{$\begin{array}{l}\text { Microorganism } \\
\text { species or source } \\
\text { of isolation }\end{array}$} & \multirow[b]{2}{*}{ Disease } & \multicolumn{3}{|c|}{ Conventional PCR ${ }^{\mathbf{l}}$} & \multicolumn{6}{|c|}{ Real-time $\mathbf{P C R}^{\mathrm{m}}$} \\
\hline & & $\begin{array}{l}\text { ZCf/ } \\
\text { OI2cn }\end{array}$ & $\begin{array}{l}\text { OA2/ } \\
\text { OI2 }{ }^{0}\end{array}$ & $\begin{array}{l}\text { LpFrag4- } \\
\text { 1611F/480Rp }\end{array}$ & $\mathbf{C t}$ & $\begin{array}{l}\text { ZCf/HLBr/ } \\
\text { HLBp }^{q}\end{array}$ & $\mathbf{C t}$ & $\begin{array}{l}\text { LpsF/LpsR/ } \\
\text { LpsPr }\end{array}$ & $\mathbf{C t}$ & $\begin{array}{l}\text { CL-ZC-F/ } \\
\text { CL-ZC-R }\end{array}$ \\
\hline 'Ca. L. africanus't & HLB of citrus & + & - & - & 24.6 & + & 0.0 & - & 0.0 & - \\
\hline ' $C a$. L. americanus't & HLB of citrus & - & - & - & 0.0 & - & 0.0 & - & 0.0 & - \\
\hline 'Ca. L. asiaticus'u & HLB of citrus & - & - & - & 36.0 & - & 0.0 & - & 0.0 & - \\
\hline 'Ca. L. africanus'u & HLB of citrus & - & - & - & 35.2 & - & 38.4 & - & 0.0 & - \\
\hline 'Ca. L. asiaticus'v & HLB of citrus & - & - & - & 32.4 & + & 39.6 & - & 0.0 & - \\
\hline 'Ca. L. asiaticus'w & HLB of citrus & - & - & - & 30.9 & + & 36.0 & - & 0.0 & - \\
\hline $\begin{array}{l}\text { 'Ca. Phytoplasma } \\
\text { aurantifolia' }\end{array}$ & Witches'-broom & - & - & - & 0.0 & - & 0.0 & - & 0.0 & - \\
\hline 'Ca. Phytoplasma' sp. & Purple top & - & - & - & 0.0 & - & 0.0 & - & 0.0 & - \\
\hline 'Ca. Phytoplasma' sp. & Clover proliferation & - & - & - & 0.0 & - & 0.0 & - & 0.0 & - \\
\hline 'Ca. P. americanum' & $\begin{array}{l}\text { Stolbur-like } \\
\text { phytoplasma }\end{array}$ & - & - & - & 36.4 & - & 0.0 & - & 0.0 & - \\
\hline $\begin{array}{l}\text { P. carotovorum } \\
\text { subsp. }^{\text {carotovorum }}{ }^{\mathrm{x}}\end{array}$ & Soft rot & - & - & - & 37.9 & - & 0.0 & - & 0.0 & - \\
\hline $\begin{array}{l}\text { P. carotovorum } \\
\text { subsp. atroseptica }^{\mathrm{x}}\end{array}$ & Blackleg & - & - & - & 38.0 & - & 0.0 & - & 0.0 & - \\
\hline $\begin{array}{l}\text { Clavibacter } \\
\text { michiganense subsp. } \\
\text { sepedonicum }^{\mathrm{x}}\end{array}$ & Bacterial ring rot & - & - & - & 37.6 & - & 0.0 & - & 0.0 & - \\
\hline Streptomyces scabies $\mathrm{x}$ & Common scab & - & - & - & 0.0 & - & 0.0 & - & 0.0 & - \\
\hline Serratia marcescens $\mathrm{s}^{\mathrm{x}}$ & $\begin{array}{l}\text { Ubiquitous } \\
\text { bacterium found } \\
\text { on potato plants }\end{array}$ & - & - & - & 39.0 & - & 0.0 & - & 0.0 & - \\
\hline HW05MN & Haywire & - & - & - & 0.0 & - & 0.0 & - & 0.0 & - \\
\hline HW07MN & Haywire & - & - & - & 0.0 & - & 0.0 & - & 0.0 & - \\
\hline HW05FL18 & Haywire & + & + & + & 30.6 & + & 30.6 & + & 0.0 & - \\
\hline HW08NE163 & Haywire & + & + & + & 31.6 & + & 31.6 & + & 0.0 & - \\
\hline HW08NE162 & Haywire & + & + & + & 31.9 & + & 30.6 & + & 0.0 & - \\
\hline PY08TX214 & Psyllid-yellows & - & - & + & 33.9 & + & 0.0 & - & 33.9 & + \\
\hline PY08TX191 & Psyllid-yellows & + & + & - & 32.4 & + & 31.5 & + & 0.0 & - \\
\hline PY08TX192 & Psyllid-yellows & + & + & - & 32.5 & + & 33.5 & + & 34.6 & + \\
\hline PY08NE199 & Psyllid-yellows & + & + & + & 34.1 & + & 33.7 & + & 0.0 & - \\
\hline PY08KS178 & Psyllid-yellows & + & + & + & 27.7 & + & 25.0 & + & 23.8 & + \\
\hline PY08KS181 & Psyllid-yellows & + & + & + & 32.3 & + & 30.6 & + & 29.7 & + \\
\hline 'Ca. L. solanacearum'y & & + & + & + & $\mathrm{NT}^{\mathrm{z}}$ & & NT & & NT & \\
\hline Healthy potato & & - & - & - & 0.0 & - & 0.0 & - & 0.0 & - \\
\hline Healthy citrus & & - & - & - & 0.0 & - & 0.0 & - & 0.0 & - \\
\hline Healthy periwinkle & & - & - & - & 0.0 & - & 0.0 & - & 0.0 & - \\
\hline Water & & - & - & - & 0.0 & - & 0.0 & - & 0.0 & - \\
\hline
\end{tabular}

${ }^{1}$ Positive or negative results denoted as $+/-$, respectively. Samples with no visual band displayed on an agarose gel were considered negative.

m Positive or negative results denoted as $+/-$, respectively. Samples with mean crossing threshold values $(\mathrm{Ct})$ greater than 35 were considered negative.

${ }^{\mathrm{n}}$ Primers from this study.

${ }^{\circ}$ Primers by Liefting et al. (20).

p Primers by Hansen et al. (11).

q Primers from this study.

r Primers and probe from this study.

s Primers by H. Lin (unpublished).

t DNA samples from Sandrine Eveillard (INRA, Bordeaux, France).

" DNA samples prepared in May 2009.

v DNA samples prepared in December 2008.

${ }^{w}$ DNA samples from Nian Wang (Citrus Research and Education Center, University of Florida, Lake Alfred).

${ }^{x}$ DNA samples prepared from pure culture.

y 'Ca. L. solanacearum' positive control DNA from Lia Liefting (MAF Biosecurity New Zealand, Auckland).

z NT: not tested. 
using primers $\mathrm{ZCf} / \mathrm{OI} 2 \mathrm{c}$, and 40 positive samples were amplified using primers of Hansen et al. (11). PCR amplicons were purified using the QIAquick PCR Purification Kit (Qiagen) and sequenced by the Cornell DNA Sequencing Facilities (Ithaca, NY). Sequences were assembled and aligned using BioEdit package version 7.0.9 (Ibis Biosciences, Carlsbad, CA). The sequences reported in this study have been deposited in GenBank (accession nos. FJ829800-FJ829815 and FJ830690FJ830706). Reference sequences of ' $\mathrm{Ca}$. L. asiaticus', 'Ca. L. africanus', 'Ca. L. americanus', ' $\mathrm{Ca}$. L. solanacearum', and ' $C a$. L. psyllaurous' were obtained from GenBank, accession nos. AF137368, AY742824, FJ263691, FJ263692, FJ196314, EU754741, EU754742, EU812556, EU812557, EU812558, EU812559, EU935004, EU921627, EU980389, EU918194, EU918195, EU918196, EU918197, EU834130, FJ263689, FJ236554, FJ263704, DQ778016, and L22533.

Statistical and phylogenetic analysis. The parameter estimates of slope and intercept of the lines resulting from the regression analysis of $\mathrm{Ct}$ value and DNA concentration $(\mathrm{ng} / \mu \mathrm{l})$ using real-time PCR primers/probes $\mathrm{LpsF} / \mathrm{LpsR} / \mathrm{LpsP}$ and CLZC-F/CL-ZC-R were compared with the lines resulting from real-time PCR primers/probe ZCf/HLBr/HLBp, which was used as a reference for analysis.

The relationship between detection of ' $C a$. L. solanacearum' in the samples tested, PCR method, and tissue source was assessed using a logit analysis (2). Initially, a two-factor model was fit with the main effects of PCR method and tissue type, plus the interaction between them. The interaction term was deemed not significant (Wald chi-square $=1.34 ; P=0.998$ ), and a main effects model then was fit. Follow-up pair-wise comparisons on levels within each main effect were performed using contrasts within the logit analysis (2). The probability of a type I error, in this case a false positive, for pair-wise comparisons within a main effect was set to $5 \%$.

Phylogenetic trees were constructed by the Molecular Evolutionary Genetics Analysis software (MEGA v 4.1) using neighbor-joining distances (15). Statistical confidences were assessed by 1,000 bootstrap replications. The datasets contained a total of $1,171 \mathrm{bp}$ for the $16 \mathrm{~S}$ rDNA region and 946 or $948 \mathrm{bp}$ for ISR-23S rDNA.

\section{RESULTS}

Specificity of conventional and realtime PCR assays. ' $\mathrm{Ca}$. P. americanum' was detected in less than $1 \%$ of archived ZC samples from Texas collected from 2005 to 2007 (data not shown). Phytoplasma-negative samples were tested further for the presence of ' $\mathrm{Ca}$. L. solanacearum'. Conventional and real-time PCR assays differed in specificity among the selected phylogenetically and ecologically related microorganism species. Conventional PCR assays with primer set OA2/OI2c (20) and LpFrag4-1611F/480R yielded negative results for HLB citrus pathogens and prokaryotic potato pathogens; however, cPCR assays with primer set ZCf/OI2c amplified ' $\mathrm{Ca}$. L. africanus' DNA from France, but yielded negative results for the remainder of the microorganisms evaluated (Table 1). The amplicon from the ' $C a$. L. africanus' DNA was sequenced, and BLAST results showed that it was most closely related to the ' $\mathrm{Ca}$. L. africanus' sequences in GenBank with nucleotide identities ranging from 98.6 to $99.5 \%$. This ' $\mathrm{Ca}$. L. africanus' DNA only shared 97.2 to $97.6 \%$ identities in their $16 \mathrm{~S}$ rDNA sequences with ' $\mathrm{Ca}$. L. solanacearum' or ' $\mathrm{Ca}$. L. psyllaurous', the $\mathrm{ZC}$ associated liberibacter. However, this ' $\mathrm{Ca}$. L. africanus' displayed complete sequence identity with ZC-associated ' $\mathrm{Ca}$. L. solanacearum' in the ZCf primer region, which explained the amplification using $\mathrm{ZCf} / \mathrm{OI} 2 \mathrm{c}$. In preliminary evaluations, cPCR assays using all three primer sets resulted in amplicons of the appropriate size when testing potato plants afflicted with PY and HW. Therefore, additional samples of PY and HW were tested. Out of 6 PY-affected potato plants collected from Kansas, Texas, and Nebraska, 5, 5, and 4 samples yielded ' $C a$. L. solanacearum' positive results using primers ZCf/OI2c, OA2/OI2c, and LpFrag4-1611F/480R, respectively (Table 1). Out of $5 \mathrm{HW}$ samples, none of the two Minnesota samples collected in 2005 and 2007 was ' $\mathrm{Ca}$. L. solanacearum' positive, although the Florida sample collected in 2005 and both Nebraska samples collected in 2008 were ' $\mathrm{Ca}$. L. solanacearum' positive with all three cPCR assays (Table 1). All of the plants collected from Texas in 2008 with HW symptoms tested positive for ' $\mathrm{Ca}$. L. solanacearum'.

In real-time PCR assays, the $\mathrm{ZCf} /$ $\mathrm{HLBp} / \mathrm{HLBr}$ primers amplified ' $\mathrm{Ca}$. L. asiaticus' DNA from France and Florida, ' $C a$. L. africanus' DNA from France, PY samples, and HW samples from Nebraska and Florida, whereas results were negative with the LpsF/LpsR/LpsP and CLZC-F/CL-ZC-R primers for HLB citrus pathogens and prokaryotic potato pathogens except for HW and PY (Table 1). LpsF/LpsR/LpsP detected ' $C a$. L. solanacearum' in HW samples from Florida and Nebraska, but not in HW samples from Minnesota; CL-ZC-F/CL-ZC-R yielded negative results with $\mathrm{HW}$ samples from Minnesota and Nebraska, and only gave ' $C a$. L. solanacearum' positive results with the HW sample from Florida. Out of the 6 PY samples, 5 and 4 samples were ' $C a$. L. solanacearum' positive using LpsF/LpsR/LpsP and CL-ZC-F/CL-ZC-R, respectively.
Sensitivity of conventional and realtime PCR assays. Since ' $C a$. L. solanacearum' has yet to be cultured, twofold serial dilutions of total DNA extracts from $\mathrm{ZC}$ potato tissues were used in the sensitivity evaluation for conventional and realtime PCR assays. Therefore, detection limits derived from this study were based on the total DNA concentration. Results determined that the detection limit was 0.19 to $1.56 \mathrm{ng}$ of total DNA per reaction, 0.39 to $1.56 \mathrm{ng}$ per reaction, and 0.39 to $0.78 \mathrm{ng}$ per reaction for primers $\mathrm{ZCf} / \mathrm{OI} 2 \mathrm{c}$, OA2/OI2c, and LpFrag4-1611F/480R, respectively (Fig. 3).

Regression analysis results comparing real-time PCR assays indicate no consistent significant differences in sensitivity when these primer sets were used to assay four ZC-affected plant samples. For example, there was no significant difference observed between regression lines generated by $\mathrm{LpsF} / \mathrm{LpsR} / \mathrm{LpsP}(P=0.4751)$ and CL-ZC-F/CL-ZC-R $(P=0.1024)$ compared to the line generated by $\mathrm{ZCf} /$ $\mathrm{HLBp} / \mathrm{HLBr}$, or between lines resulting from the LpsF/LpsR/LpsP and CL-ZCF/CL-ZC-R primer sets $(P=0.2047)$ (Fig. 4A) when evaluating sample ZC06TX342. Contrary to this, significant differences were observed between lines generated by both $\mathrm{LpsF} / \mathrm{LpsR} / \mathrm{LpsP} \quad(P=0.0060$; $0.0056)$ and CL-ZC-F/CL-ZC-R $(P=$ $0.0272 ;<0.0001)$ when compared to ZCf/HLBp/HLBr with samples ZC06TX362 and ZC06TX49-3, respectively (Fig. 4B and C). In the case of $\mathrm{LpsF} / \mathrm{LpsR} / \mathrm{LpsP}$, this difference was due to the increase in the Y-intercept $(P=0.0192 ; 0.0158)$ and the slope $(P=0.0016 ; 0.0025)$ of the line for both samples (Fig. 4B and C). However, the situation was different with CLZC-F/CL-ZC-R primers. For sample ZC06TX36-2, a significant difference was not detected in the intercept $(P=0.0840)$ but was in the slope $(P=0.0129)$ (Fig. 4B). Contrary to this, using CL-ZC-F/ CL-ZC-R primers to assay sample ZC06TX49-3, a significant difference was observed in the intercept $(P=$ $0.0004)$ but not in the slope $(P=0.4106)$ (Fig. 4C). A significant difference was not observed between regression lines of LpsF/LpsR/LpsP and CL-ZC-F/CL-ZC-R when testing sample ZC06TX36-2 ( $P=$ $0.9627)$, while the two were significantly different from sample ZC06TX49-3 $(P<$ $0.0001)$. Regression analyses for sample ZC08MX211 were again different from the other three samples (Fig. 4D). Here, the line resulting from $\mathrm{LpsF} / \mathrm{LpsR} / \mathrm{LpsP}$ was not significantly different from ZCf/HLBp/HLBr $(P=0.0762)$, while the line resulting from CL-ZC-F/CL-ZC-R was significantly different from $\mathrm{ZCf} /$ HLBp/HLBr $(P=0.0051)$ due to both the slope $(P=0.0018)$ and intercept $(P=$ 0.0093). Regression lines resulting from LpsF/LpsR/LpsP and CL-ZC-F/CL-ZC-R were not significantly different from each 
other for sample ZC08MX211 $(P=$ 0.2714).

Optimization of multiplex PCR assays and specificity of $\beta$-tubulin primers for solanaceous plants. A multiplex cPCR strategy was developed to account for template DNA quality effects within each reaction. Multiplex PCR assays were developed and optimized with primer sets Btub1F-R/ZCf-OI2c or Btub2F-R/OA2OI2c using Platinum Taq polymerase or Phusion DNA polymerase. Primer ratios of $1: 1,2: 1,2.5: 1,2.75: 1$, and $3: 1$ were tested using DNA extracts of healthy $(\mathrm{H} 2)$ and ZC-affected potato plants (i.e., ZC5 and $\mathrm{DD}$, representing samples from two geo- graphic regions) using Platinum Taq polymerase (Fig. 5A). A 1:1 ratio of both primer pairs only allowed amplification of the most abundant target, the potato $\beta$ tubulin gene. A twofold reduction in $\beta$ tubulin primer concentration was adequate to allow amplification of both target DNA regions. Sample ZC5 was best evaluated at a primer ratio concentration of 2:1. However, for sample DD the multiplex PCR yielded both amplicons with all primer concentration ratios, except the 1:1 ratio. Differences in ' $\mathrm{Ca}$. Liberibacter' DNA target concentration in the sample may explain these results. Multiplex results using Phusion polymerase were very simi- lar (data not shown). The optimized multiplex PCR assays included $0.4 \mu \mathrm{M}$ of $\mathrm{ZCf} / \mathrm{OI} 2 \mathrm{c}$ with $0.2 \mu \mathrm{M}$ of Btub1F/R or 0.4 $\mu \mathrm{M}$ of $\mathrm{OA} 2 / \mathrm{OI} 2 \mathrm{c}$ with $0.13 \mu \mathrm{M}$ of Btub2F/R using Platinum DNA polymerase under PCR conditions as described previously and according to Liefting et al. (20), respectively. The newly designed $\beta$-tubulin primers, Btub1F/R, were tested in a PCR reaction using DNA samples from various solanaceous species, and the $\beta$-tubulin DNA region was specifically amplified for each species (Fig. 5B). The identity of the amplicons was confirmed by DNA sequencing (data not shown).

$\mathrm{zCf} / \mathrm{Ol2c}$

OA2/OI2C

LpFrag4-1611F/480R
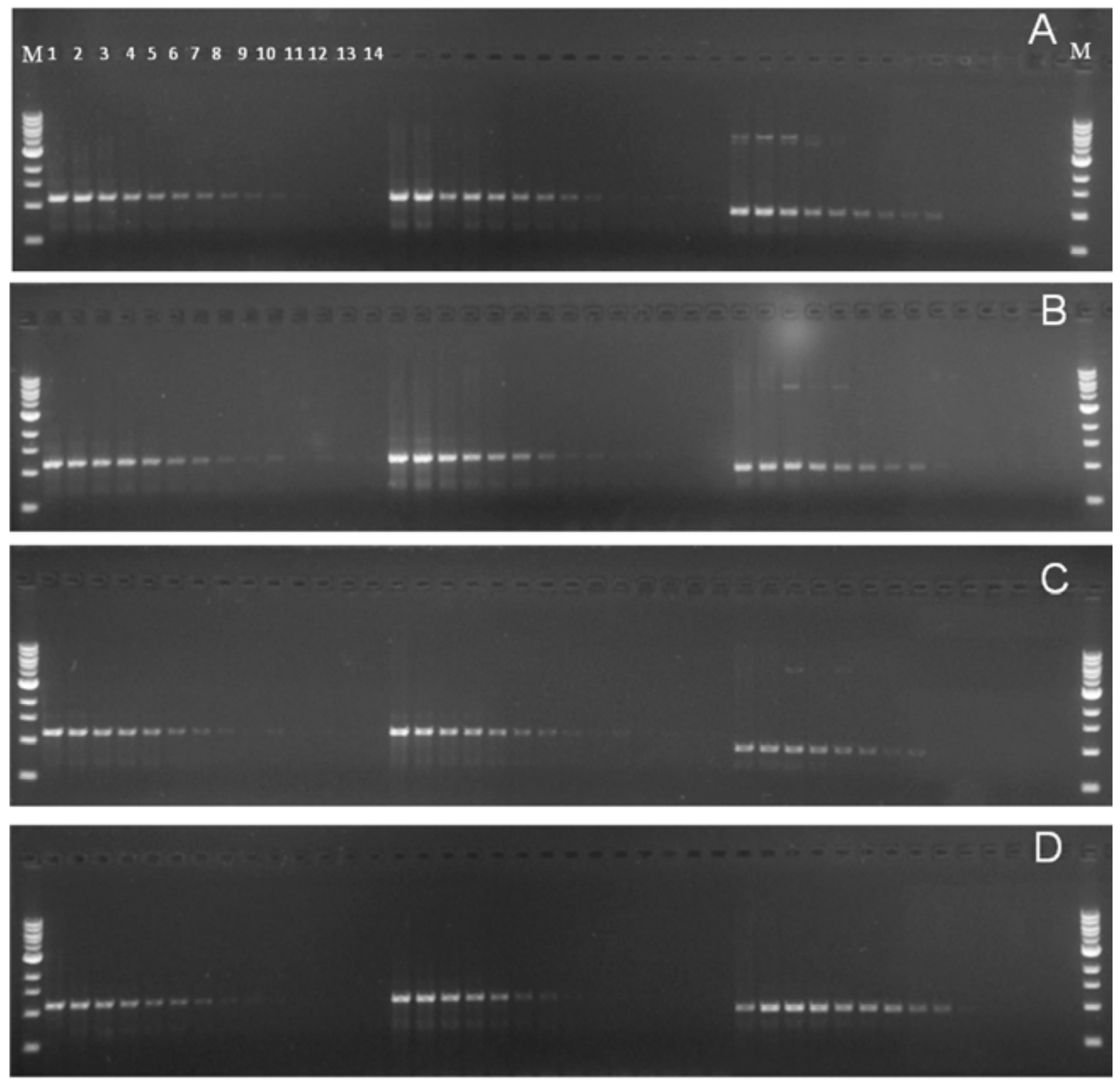

Fig. 3. Sensitivity of conventional polymerase chain reaction (cPCR) assays used to detect 'Candidatus Liberibacter' species in DNA samples A, ZC06TX34-2, B, ZC06TX36-2, C, ZC06TX49-3, and D, ZC08MX211. Marker (M) was $1 \mathrm{~kb}$ DNA ladder (New England BioLabs). Lanes 1 to 14 were loaded with PCR amplicons from twofold serial dilutions of each sample with a starting concentration $100 \mathrm{ng} / \mu$. Each image consists of three PCR tests on the same set of sample dilutions using primers ZCf/OI2c, OA2/OI2c (20), and LpFrag4-1611F/480R (11) from left to right, respectively. The sizes of the PCR amplicon with ZCf/OI2c, OA2/OI2c, and LpFrag4-1611F/480R are 1,171, 1,168, and 948 bp, respectively. 
Detection of ' $\mathrm{Ca}$. L. solanacearum' in ZC symptomatic potato samples using conventional, multiplex, and real-time PCR assays. Efficiency of the cPCR assays was $51.1,47.8$, and $56.2 \%$ for primers ZCf/OI2c, OA2/OI2c, and LpFrag41611F/480R, respectively. ' $C a$. L. solanacearum' was detected in ZC symptomatic potato plants collected from commercial potato fields in Colorado and Florida in 2005 and in Texas from 2006 to 2008. The frequency of detection of ' $\mathrm{Ca}$. L. solanacearum' from ZC symptomatic tissues using all cPCR primers was higher for samples collected in 2007 and 2008 compared with previous years (data not shown). Detection frequencies ranged from 45.3 to $64.8 \%$ when DNA was extracted from stems, stolons, and tubers compared to 7.7 to $26.2 \%$ from leaf petioles across all cPCR assays. 'Ca. L. solanacearum' could not be detected from leaflet mid- veins regardless of the primers used in cPCR. Using real-time PCR, detection frequencies ranged from 31.6 to $61.1 \%$ for stem, stolon, and tuber tissue, regardless of the primers used, and from 23.1 to $30.8 \%$ in leaf petioles (data not shown). ' $\mathrm{Ca}$. L. solanacearum' was detected also in ZC symptomatic potato plants collected from additional states in 2008 including Kansas, Colorado, and Nebraska and from young potato seedling plants with symptoms of HW grown from seed produced in Wyoming.

The distribution of ' $\mathrm{Ca}$. L. solanacearum' in $12 \mathrm{ZC}$ symptomatic potato plants collected from commercial potato fields suggests higher concentrations of the pathogen are found in belowground compared to aboveground tissues when tested using the three cPCR assays and one realtime PCR assay using $\mathrm{ZCf} / \mathrm{HLBr} / \mathrm{HLBp}$ primers and probe on the same set of DNA samples (Table 2). Frequency of detection was significantly different among the tissues sampled, ranging from 91.7 to $100.0 \%$ in stolon tissues to 0.0 to $83.3 \%$ in leaf, midvein, petiole, and stem tissues. Among the aboveground tissues, ' $\mathrm{Ca}$. L. solanacearum' was detected most frequently in stem tissue. There were significant differences in detection among the three conventional and one real-time PCR assays used. The cPCR assay using primers LpFrag4-1611F/480R detected ' $C a$. L. solanacearum' significantly more frequently than the other two cPCR assays ( $P$ $=0.0085 ; P=0.0002$ ), but not significantly more frequently than the real-time PCR assay using ZCf/HLBr/HLBp ( $P=$ 0.3354).

Among the 594 ZC potato samples, 480 produced the amplicon of the internal control gene in the multiplex PCR assays. Therefore, the samples with PCR-quality
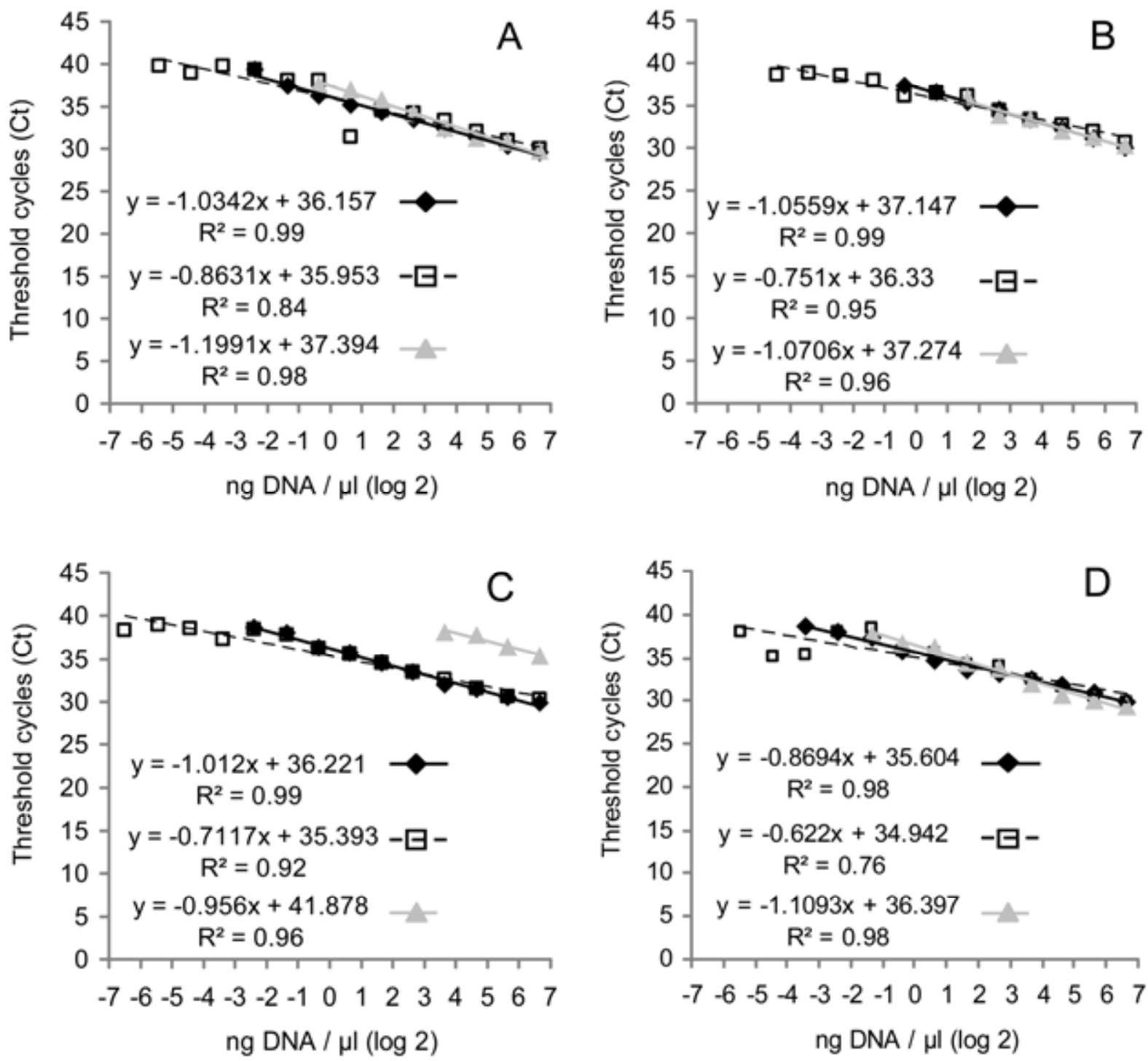

ng DNA / $\mu \mathrm{l}(\log 2)$

Fig. 4. Sensitivity of real-time polymerase chain reaction (PCR) assays using LpsF/LpsR/LpsP (diamond), ZCf/HLBr/HLBp (open box), and CL-ZC-F/CLZC-R (triangle) to detect 'Candidatus Liberibacter' species in DNA samples A, ZC06TX34-2, B, ZC06TX36-2, C, ZC06TX49-3, and D, ZC08MX211. A total of 40 PCR cycles were performed. Threshold cycle $(\mathrm{Ct})$ values achieved within those 40 cycles resulted in data points, therefore differences in sensitivities are reflected in the number of data points displayed on the graphs for each primer set. Each data point is the mean of two trials at each concentration of DNA for each PCR primer. 
DNA are $80.8 \%$. Detection frequency based on the $480 \mathrm{ZC}$-affected potato samples was $32.9 \%$ for primers $\mathrm{ZCf} / \mathrm{OI} 2 \mathrm{c} /$ Btub1F/R and $22.2 \%$ for primers OA2/ $\mathrm{OI} 2 \mathrm{c} / \mathrm{Btub} 2 \mathrm{~F} / \mathrm{R}$, respectively.

Detection in plant hosts and psyllids using conventional and real-time PCR assays. ' $C a$. L. solanacearum' was detected in 8,6 , and 5 of 22 silverleaf nightshade plants tested with $\mathrm{ZCf} / \mathrm{OI} 2 \mathrm{c}, \mathrm{OA} 2 /$ OI2c, and LpFrag4-1611F/480R cPCR assays, respectively, and 10,2, and 0 plants tested with ZCf/HLBr/HLBp, LpsF/LpsR/ LpsP, and CL-ZC-F/CL-ZC-R real-time
PCR assays, respectively. ZCf/OI2c cPCR assay was the most sensitive assay for detecting ' $\mathrm{Ca}$. L. solanacearum' in black nightshade, silverleaf nightshade, wolfberry, and tomato plants with foliar symptoms consistent with ZC and infested with psyllids. OA2/OI2c cPCR detected ' $\mathrm{Ca}$. L. solanacearum' in black nightshade and silverleaf nightshade; whereas LpFrag4$1611 \mathrm{~F} / 480 \mathrm{R}$ only detected it in silverleaf nightshade and not in any of the other aforementioned weed hosts assayed. Interestingly, LpFrag4-1611F/480R was also the only cPCR assay to detect it in healthy
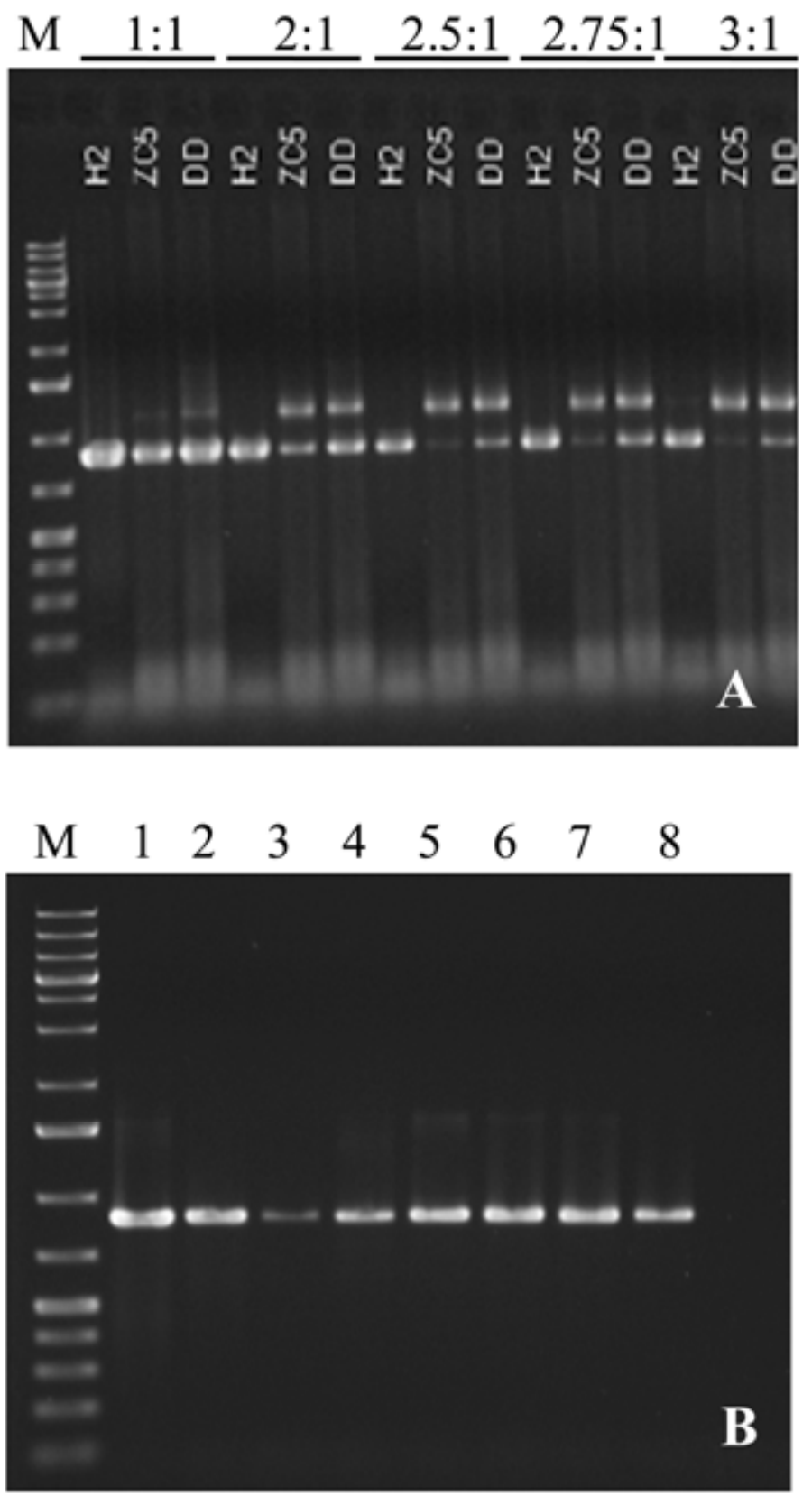

Fig. 5. A, Multiplex polymerase chain reaction optimization using Platinum Taq DNA polymerase. Primer ratios are $0.4 \mu \mathrm{M}$ for $\mathrm{ZCf} / \mathrm{OI} 2 \mathrm{c}$ and varying concentrations of $\beta$-tubulin1 F-R $(0.4,0.2,0.16$, 0.145 , and $0.133 \mu \mathrm{M}) . \beta$ : $\beta$-tubulin, $\mathrm{H} 2$ : healthy potato tissue, and ZC5 and DD represent two zebra complex-afflicted plants from two different locations. DNA marker: O'Gene Ruler $1 \mathrm{~kb}$ DNA Ladder Plus (Glen Burnie, MD). B, The specific amplification with Btub1F/R from different solanaceous species. 1: Solanum tuberosum, 2: S. lycopersicum, 3: Capsicum annuum, 4: Nicotiana benthamiana (WT), 5: N. benthamiana (16C GFP-transgenic), 6: N. tabacum Glurk, 7: N. tabacum Turk, 8: N. sylvestris. $\beta$ : $\beta$-tubulin. DNA marker: O'Gene Ruler 1 kb DNA Ladder Plus (Glen Burnie, MD).

jalapeno pepper plants infested with psyllids. With real-time PCR assays, primerprobe set $\mathrm{ZCf} / \mathrm{HLBr} / \mathrm{HLBp}$ detected ' $\mathrm{Ca}$. L. solanacearum' in black nightshade, silverleaf nightshade, and jalapeno pepper plants, and primer-probe set LpsF/LpsR/ LpsP detected it in silverleaf nightshade plants only, whereas CL-ZC-F/CL-ZC-R did not detect it in any of the selected hosts.

The presence of ' $\mathrm{Ca}$. L. solanacearum' in psyllids collected from potato, tomato, and jalapeno pepper plants was assessed in 264 samples by multiplex real-time PCR assays with primers that targeted the psyllid Cox gene as an internal control (17) ' $\mathrm{Ca}$. L. solanacearum' was detected only in one single adult psyllid collected in Olton, TX on 7 August 2008. Sixty-two of these DNA extracts were also evaluated using real-time PCR for the presence of ' $\mathrm{Ca}$. P. americanus', Arsenophonus sp., Mycsymbiont, Wolbachia sp., and Synsymbiont. ' $C a$. P. americanus' and Synsymbiont were not detected in any of the 62 DNA extracts. The infection incidence of Arsenophonus sp. was 37.9, 63.2, and $78.6 \%$ for DNA extracts from sampling groups I, II, and III, respectively. The infection incidence of Wolbachia sp. was $60.0,95.0$, and $82.4 \%$ for group I, II, and III, respectively. The infection incidence of Carsonella ruddi (Myc-symbiont) was 0.0, 21.1 , and $7.1 \%$ for group I, II, and III, respectively.

Genetic variation among ' $\mathrm{Ca}$. $\mathrm{L}$. solanacearum' detected from commercial field potato samples. Two singlenucleotide polymorphisms (SNP) were found at positions of 236 and 608 of the $1,171 \mathrm{bp}$ of the $16 \mathrm{~S}$ rDNA region amplified by ZCf/OI2c primers among 39 ' $\mathrm{Ca}$. L. solanacearum' "strains". These "strains" were separated into two clusters as shown in the neighbor-joining phylogenetic tree, clades $1(\mathrm{C} 1)$ and $2(\mathrm{C} 2)$, respectively (Fig. 6). Sequences of $\mathrm{C} 1$ shared $99.8 \%$ similarity with C2, 99.8 to $100.0 \%$ with that of ZC ' $C a$. Liberibacter' strains obtained from GenBank, and 94.8 to $97.1 \%$ with the sequences of HLB pathogens ' $\mathrm{Ca}$. L. africanus', 'Ca. L. americanus', and ' $\mathrm{Ca}$. L. asiaticus'. Six SNP were found among the 40 'Ca. L. solanacearum' "strains" at positions of 1891 to 1892,1901 to 1902,1977 , 2089, 2252, and 2294 on 946 or 948 bp of the partial ISR-23S rRNA gene amplified by Lp Frag 4-1161 F and 480R primers (11). These ' $\mathrm{Ca}$. L. solanacearum' "strains" were separated into two clades, $\mathrm{C} 1$ and $\mathrm{C} 2$, respectively (Fig. 7). Sequences of $\mathrm{C} 1$ shared $99.3 \%$ similarity with C2, 99.8 to $100.0 \%$ with ZC ' $\mathrm{Ca}$. Liberibacter' sequences obtained from GenBank, and 85.6 to $90.5 \%$ with HLB pathogens ' $C a$. L. africanus', ' $C a$. L. americanus', and ' $\mathrm{Ca}$. L. asiaticus'. A similar phylogeny based on partial ISR23S rDNA sequences resulted in identical clades. Thus, from this partial 16S-ISR- 
23S rDNA region $(1,171 \mathrm{bp}$ for $16 \mathrm{~S}$ rDNA and 946 or 948 bp for ISR-23S rDNA), there were a total of $8 \mathrm{SNP}$ among the " $\mathrm{Ca}$. L. solanacearum' "strains" investigated in this study.

Interestingly, both HW and PY samples were divided between $\mathrm{ZC}$ clades $\mathrm{C} 1$ and C2 within 16S-ISR-23S rDNA region. Two HW samples, 05FL18 and 08NE163, belonged to $\mathrm{C} 1$, and three HW samples, 08NE162, 08TX171, and 08TX159, belonged to $\mathrm{C} 2$; whereas four PY samples, 08NE199, 08TX190, 08TX191, and 08TX192, clustered with C1, and two PY samples, 08KS178 and 08KS181, clustered with $\mathrm{C} 2$ in phylogenetic trees constructed based on either $16 \mathrm{~S}$ rDNA or partial ISR23S rDNA gene sequences.

\section{DISCUSSION}

$\mathrm{ZC}$ has become an economically damaging disease of potato in the United States over the short period of time since it was reported in 2000 (34). Personal accounts from potato growers in Texas indicate that $\mathrm{ZC}$ has caused millions of dollars in losses and has resulted in a reduction in the total hectarage of the winter and spring potato crops by $>20 \%$. For these reasons, the recent discovery of ' $\mathrm{Ca}$. Liberibacter' species associated with ZC was extremely important and will facilitate further studies to elucidate the etiology and epidemiology of the pathogen $(1,5,6,19-22,31,34)$. Additionally, the association of ' $\mathrm{Ca}$. L. solanacearum' with ZC and the discovery of the potato psyllid as the vector $(13,28-30,34)$ should facilitate these studies.

In studies reported here, we demonstrate for the first time, using three independent PCR-based detection strategies and different primer sets, that the BLO associated with $\mathrm{ZC}$ is also present in other potato production areas, such as Kansas, Nebraska, Colorado, Wyoming, and Mexico. This is the first report of the ZC-associated liberibacter in a number of these states, and these data clearly indicate that the ' $\mathrm{Ca}$. L. solanacearum' bacterium associated with ZC is much more widespread than previously reported. These data also suggest that ' $\mathrm{Ca}$. L. solanacearum' may be spreading. However, its distribution is likely limited by the movement of its vector, B. cockerelli. Seed transmission is also likely, but its importance is not completely understood at this time (12). In data reported here, we confirmed the presence of ' $C a$. L. solanacearum' in recently emerged potato plants with symptoms referred to as HW. These plants were less than 3 weeks old and were derived from seed tubers with characteristic symptoms of ZC. The certified seed lot from which these plants were obtained had been produced in Wyoming. These results are important for two reasons. First, ZC and ' $\mathrm{Ca}$. L. solanacearum' distribution extend farther north than previously believed, and secondly, significant questions about the role of seed transmis- sion in the distribution of the potential pathogen are raised.

Three conventional and three real-time PCR assays were compared for sensitivity and specificity in detecting ' $\mathrm{Ca}$. L. solanacearum'. All assays displayed high specificity in detecting ' $\mathrm{Ca}$. L. solanacearum' but did not give false positives with any of the other prokaryotic plant pathogens affecting potato. However, some of the primers cross-reacted with HLB-associated liberibacter; in particular, ZCf/HLBr/ HLBp consistently detected ' $C a$. L. asiaticus'. This is not surprising given that the $16 \mathrm{~S}$ rDNA region amplified by the $\mathrm{ZCf}$ primer shares a high degree of similarity among ' $\mathrm{Ca}$. Liberibacter' species that have been described to date (34), and that both $\mathrm{OI} 2 \mathrm{c}$ in cPCR and $\mathrm{HLBr}$ in real-time PCR are liberibacter-universal primers. Depending on the sample, cPCR assays were capable of successfully detecting ' $\mathrm{C} a$. L. solanacearum' in reaction mixtures with as little as $0.19 \mathrm{ng}$ total DNA per reaction compared to $1.56 \mathrm{ng}$ total DNA for realtime PCR. With cPCR primers, LpFrag4$1611 \mathrm{~F}$ and LpFrag4-480R (11) tended to be slightly more sensitive than the $\mathrm{ZCf}$ and OI2c, and OA2 and OI2c (20). However, 'Ca. L. solanacearum' was detected more frequently when the $\mathrm{ZCf} / \mathrm{OI} 2 \mathrm{c}$ primers were used than when the OA2/OI2c primers were used in both CPCR and multiplex PCR. In real-time PCR, few differences in sensitivity were detected with the primerprobe combinations used. Unfortunately, the real-time PCR primer-probe combinations were generally less sensitive than the primers used in $\mathrm{CPCR}$, and these results suggest further primer design would be useful to improve detection sensitivity.

Although it remains to be proven conclusively that ' $\mathrm{Ca}$. Liberibacter' species are the causal agents of $\mathrm{ZC}$ disease in potatoes and similar diseases in other solanaceous crops, their association with the disease has been well documented $(6,19-$ $21,23,34)$. Therefore, tests for the presence of ' $\mathrm{Ca}$. Liberibacter' species are being used in the diagnosis of ZC-afflicted potato plants as well as similar diseases of other solanaceous crops such as tomatoes and peppers $(11,20)$. PCR testing using only a single set of primers to detect a microorganism does not distinguish whether negative results are due to absence of the microbe, the presence of PCR inhibitors in the DNA extracts, or poor DNA quality. For this reason, a quality control needs to be included during such testing. Therefore, a set of potato $\beta$-tubulin primers was designed to be used with a multiplex platform in combination with ' $\mathrm{Ca}$. L. solanacearum'-specific primers. The primers were based on a newly identified and sequenced region of the potato $\beta$-tubulin gene (41) and were designed for a $T_{m}$ that permitted their use in the same PCR reaction as the ' $\mathrm{Ca}$. L. solanacearum' primers. Subsequently, the multiplex PCR reaction was optimized by varying primer concentration ratios and thermal cycling conditions. Results of the screening of the 594 plant samples confirmed the value of the multiplex PCR assay. Approximately 19\% of the DNA samples tested did not produce either ' $C a$. L. solanacearum' or $\beta$-tubulin amplicons, indicating poor sample quality. The remaining samples did not display a high incidence of ' $\mathrm{Ca}$. Liberibacter', but all of them tested positive for the $\beta$ tubulin amplicon. The ability of the $\beta$ tubulin primers to amplify the same region in solanaceous hosts other than potato extends the use of this multiplex PCR diagnosis to other solanaceous species that may be hosts for ' $C a$. Liberibacter'. It is evident that the multiplex improves cPCR utility by eliminating false negatives as it provides supportive evidence that the DNA extract was of suitable quality for PCR.

Table 2. In planta distribution of 'Candidatus Liberibacter solanacearum' in 12 zebra complex symptomatic potato plants collected from commercial fields in the United States (Colorado, Florida, Kansas, Nebraska, and Texas) and Mexico from 2005 through 2008 determined using conventional and real-time polymerase chain reaction (PCR) assays

\begin{tabular}{|c|c|c|c|c|c|}
\hline \multirow[b]{3}{*}{ Plant tissue } & \multicolumn{5}{|c|}{ ‘Ca. L. solanacearum'-positive (\%) } \\
\hline & \multicolumn{3}{|c|}{ Conventional PCR } & \multirow{2}{*}{$\begin{array}{c}\text { Real-time PCR } \\
\text { ZCf/HLBr/ } \\
\text { HLBp }^{x}\end{array}$} & \multirow[b]{2}{*}{ Mean $^{y}$} \\
\hline & $\begin{array}{l}\mathrm{ZCf} / \\
\text { OI2c }\end{array}$ & $\begin{array}{l}\text { OA2/ } \\
\text { OI2 } c^{\mathrm{v}}\end{array}$ & $\begin{array}{c}\text { LpFrag4- } \\
\text { 1611F/480R }^{w}\end{array}$ & & \\
\hline Leaf & 0.0 & 0.0 & 16.7 & 8.3 & $6.3 \mathrm{~d}$ \\
\hline Midvein & 0.0 & 8.3 & 33.3 & 16.7 & $14.6 \mathrm{~d}$ \\
\hline Petiole & 16.7 & 33.3 & 50.0 & 41.7 & $35.4 \mathrm{c}$ \\
\hline Stem & 41.7 & 58.3 & 83.3 & 83.3 & $66.7 \mathrm{~b}$ \\
\hline Stolon & 91.7 & 91.7 & 100.0 & 100.0 & $95.8 \mathrm{a}$ \\
\hline $\operatorname{Mean}^{\mathrm{z}}$ & $30.0 \mathrm{c}$ & $38.3 \mathrm{bc}$ & $56.7 \mathrm{a}$ & $50.0 \mathrm{ab}$ & 43.7 \\
\hline
\end{tabular}

u Primers from this study.

${ }^{\mathrm{v}}$ Primers by Liefting et al. (20).

${ }^{w}$ Primers by Hansen et al. (11).

${ }^{x}$ Primers and probe from this study.

${ }^{y}$ Mean detection percentage for each plant tissue followed by the same letter are not significantly different using pair-wise comparisons $(\alpha=0.05)$.

${ }^{\mathrm{z}}$ Mean detection percentage for each primer set followed by the same letter are not significantly significant using pair-wise comparisons $(\alpha=0.05)$. 


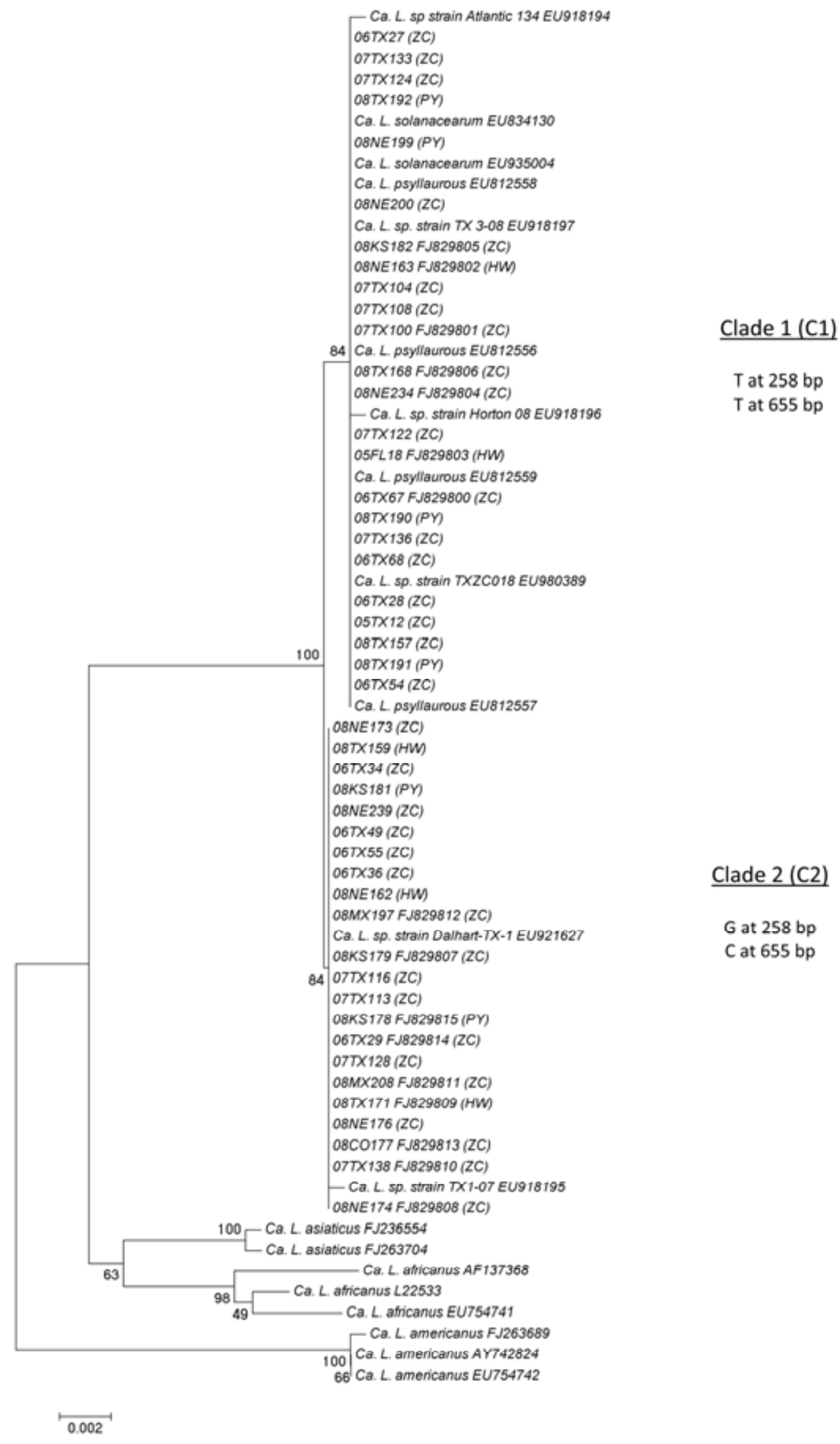

Fig. 6. Phylogenetic relationship between 39 'Candidatus Liberibacter solanacearum' "strains" in this study and other zebra chip-afflicted liberibacter sequences obtained from GenBank determined by neighbor-joining distance tree constructed with 1,171 bp of the 16S rRNA gene sequence amplified using primers ZCf and OI2c. GenBank accession numbers are indicated. Scale bar shows inferred number of changes per site. Bootstrap values (\%) are indicated at the nodes. ZC: zebra complex, HW: haywire, PY: psyllid-yellows. Sequences labeled with ZC, HW, and PY were from this study, and nonlabeled sequences were from GenBank. 
All of the primers that have been developed and evaluated in our studies were specific for the ZC-associated liberibacters and did not cross-react with any known prokaryotic pathogens of potato except for the putative pathogens associated with PY and HW. One of the cPCR primer sets amplified ' $\mathrm{Ca}$. L. africanus' DNA, and one of the real-time PCR primer-probe combinations amplified ' $C a$. L. africanus' and ' $C a$. L. asiaticus'; however, none of these results would preclude us from using these primers in assays and future studies. Unfortunately, none of the primers was capa- ble of consistently distinguishing among ZC, PY, and HW, diseases that differ substantially in foliar and tuber symptomatology. Amplicon sequencing and phylogenetic analysis from PY- and ZC-affected potato plants strongly support our hypothesis that ' $\mathrm{Ca}$. L. psyllaurous' and ' $\mathrm{Ca}$.

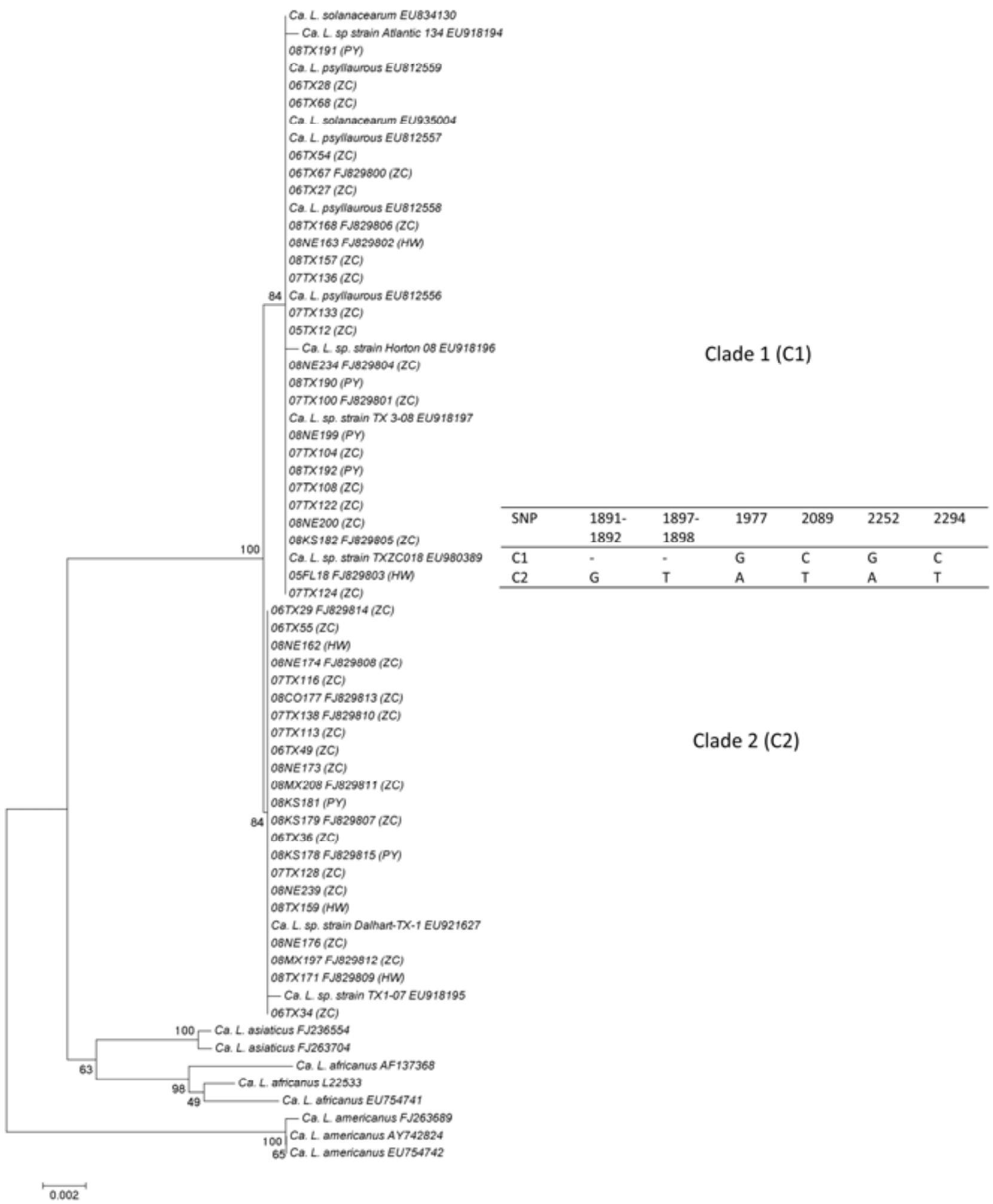

Fig. 7. Phylogenetic relationship between 40 'Candidatus Liberibacter solanacearum' "strains" in this study and other zebra chip-afflicted liberibacter sequences obtained from GenBank determined by neighbor-joining distance tree constructed with 946 or 948 bp of partial 16-ISR-23S rRNA gene sequence amplified using LpFrag4-1161F/480R primers (11). GenBank accession numbers are indicated. Scale bar shows inferred number of changes per site. Bootstrap values (\%) are indicated at the nodes. ZC: zebra complex, HW: haywire, PY: psyllid-yellows. Sequences labeled with ZC, HW, and PY were from this study, and nonlabeled sequences were from GenBank. 
L. solanacearum' belong in the same species. This was not unexpected given that one of the primer sets was developed from bacterial $16 \mathrm{~S} / 23 \mathrm{~S}$ ribosomal DNA cloned from $B$. cockerelli (11), which the investigators suggested was the cause of PY, and the other primer sets were developed from bacterial 16S rDNA obtained from ZCaffected potato plants $(17,20)$. The GenBank accessions from these three studies indicate $99.95 \%$ similarity, which is consistent with data reported here and elsewhere (34). We found very little temporal and spatial variability among the amplicons sequenced regardless of the year or geographic location from which the original ZC sample was obtained, which is consistent with studies involving molecular characterization of the entire 16S rRNA gene of ' $\mathrm{Ca}$. Liberibacter' strains associated with this disease (23). Two subclades were identified among the liberibacters detected from 39 ZC-, PY-, or HWinfected potato plants due to two base substitutions in the 16S rRNA gene region, which is in agreement with a previous study (34). However, in that study (34), amplicons from PY or HW plants were not included in the phylogenetic analysis. In addition, $6 \mathrm{SNP}$ were identified in the partial 16S-ISR-23S rRNA gene region that also separates the liberibacters detected from $40 \mathrm{ZC}-$, PY-, or $\mathrm{HW}$-affected potato plants into two subclades. Further amplification of selected ZC-, PY-, and HWaffected potato samples from $\mathrm{C} 1$ and $\mathrm{C} 2$ using a combination of ZCf and LpFrag4480R was successful; and the amplicons were sequenced. The sequence of the selected $\mathrm{C} 1$ and $\mathrm{C} 2$ strains had 8 SNP that were exactly the same as shown in the phylogenetic trees constructed using $16 \mathrm{~S}$ rDNA and 16S-ISR-23S rDNA, respectively. The results of these studies are the first time that amplicons of ' $\mathrm{Ca}$. L. solanacearum' and ' $\mathrm{Ca}$. L. psyllaurous' obtained from plants affected by ZC and PY, respectively, have been sequenced and compared directly to determine phylogenetic similarity. Clearly, ' $\mathrm{Ca}$. L. psyllaurous' and ' $\mathrm{Ca}$. L. solanacearum' are synonymous names, as previously suggested (34) and proved in this study. Nevertheless, questions remain as to how two such distinct diseases as PY and $\mathrm{ZC}$ can be associated with the same bacterium.

Since the studies reported here clearly demonstrate that the bacteria associated with both PY and ZC are identical based on their 16S rDNA, further studies are needed in order to separate these two bacterial potato pathogens. Indeed, both ' $\mathrm{Ca}$. L. psyllaurous' $(5,6,31)$ and ' $C a$. L. solanacearum' $(17,22,34)$ have been associated with $\mathrm{ZC}$, and the relationship between $\mathrm{PY}$ and $\mathrm{ZC}$ with that of ' $\mathrm{Ca}$. L. psyllaurous' and ' $\mathrm{Ca}$. L. solanacearum' have been discussed previously (34). Despite the similarities of $16 \mathrm{~S}$ rDNA of ' $\mathrm{Ca}$. L. psyllaurous' and ' $\mathrm{Ca}$. L. solanacearum', differ- ences in virulence appear to exist, and these differences may be evident elsewhere in the genome. Genome sequencing of the ' $C a$. Liberibacter' sp. associated with ZC, as has been done with ' $\mathrm{Ca}$. L. asiaticus' (9), may help elucidate the differences that appear to exist between these two species. It is possible that ' $C a$. L. psyllaurous', associated with PY, and ' $\mathrm{Ca}$. L. solanacearum', associated with ZC, may actually be pathotypes of the same species rather than two distinct species. As we suggest, genetic differences may exist between the pathotypes of ' $\mathrm{Ca}$. Liberibacter' sp. associated with ZC and PY, we acknowledge that it is premature to conclude such because the phenotype could also be influenced by a range of other factors such as environment, quantity of ' $\mathrm{Ca}$. L. solanacearum' introduced into the host, the possibility of pathogen interactions, and other unknown causes. Nonetheless, diseased potato samples with symptoms characteristic of HW (35) also tested positive for ' $\mathrm{Ca}$. L. solanacearum' in some cases. This not only raises questions regarding specificity of the PCR primers described here for the detection of the putative pathogen associated with $\mathrm{ZC}$ but also raises questions regarding the evolution of this potential pathogenic agent. Furthermore, a disease referred to as purple top wilt was described over 40 years ago with tuber symptoms very similar to those of $\mathrm{ZC}$ (37; archival find courtesy of G. A. Secor). Interestingly, the authors reported that the tuber discoloration associated with purple top wilt was found commonly in potato tubers grown in the eastern United States (37), a region where ZC has yet to be identified. Clearly, further primer development based on other genes determined by the genome project is necessary so that the ZC-associated microbe or pathogen can be unambiguously detected and distinguished from other potato diseases such as PY and HW, and perhaps purple top wilt in the eastern United States.

Previous studies have demonstrated that the HLB bacteria are not equally distributed within plant tissues of citrus trees (14,18,39). ' $C a$. L. solanacearum' is also a phloem-limited pathogen, so it was not surprising that we were able to detect this pathogen in higher frequencies in belowground potato tissues such as tubers and stolons compared to aboveground tissues. These data are consistent with those reported by Li et al. (17). Since stem tissue can become highly lignified over the course of a growing season and much more difficult to process than tuber or stolon tissue, these data demonstrate a relatively easy means to obtain DNA of the ZCassociated liberibacter for future studies.

' $\mathrm{Ca}$. Liberibacter' species have a substantial host range within the solanaceous family. In addition to potato and tomato, Capsicum sp. and Cape gooseberry are known to be hosts for this potential patho- gen $(11,19,21)$. In studies reported here, we also were able to detect ' $\mathrm{Ca}$. L. solanacearum' in a number of solanaceous hosts including silverleaf nightshade ( $S$. elaeagnifolium), wolfberry (L. barbarum), and black nightshade (S. ptychanthum). Two of these solanaceous plants are perennial weed hosts endemic to many potato production areas of Texas. Whether these plant species can act as reservoir hosts of the presumptive $\mathrm{ZC}$ pathogen and are of epidemiological importance has yet to be determined.

The infestation incidence of ' $\mathrm{Ca}$. L. solanacearum' was extremely low in all psyllid samples tested in studies reported here. This may be due to the low titer of the bacterium in the potato plants affected by $\mathrm{ZC}$ as shown in a previous study (17). The low incidence of infestation may also be due to the host tissues from which the psyllids were obtained. A large number of the psyllids used in our studies were obtained from heavily infested tomato and pepper plants near Dalhart, TX. It has been previously demonstrated that infection frequency of ' $\mathrm{Ca}$. L. psyllaurous' was substantially lower in a number of psyllid stages when they were recovered from tomato than from potato (11). Nonetheless, these results are difficult to reconcile with other studies that reported 30 to $50 \%$ transmission frequencies using caged psyllids collected from the field $(27,29,30)$. In contrast, the infestation incidence of ' $\mathrm{Ca}$. L. asiaticus' was 10 to $100 \%$ among the Asian citrus psyllids (ACP) collected on HLB-symptomatic trees in the field in Florida (18). ' $\mathrm{Ca}$. L. asiaticus' incidence in $\mathrm{ACP}$ was $45.2 \%$ in Japan, and the incidence of ' $\mathrm{Ca}$. L. africanus' was $35 \%$ in African citrus psyllids in South Africa (W. $\mathrm{Li}$, unpublished). Either the frequency of ' $C a$. L. solanacearum' infection is much lower than reported for other related bacteria that are associated with HLB (3) or better methodology is needed to improve the detection of the $\mathrm{ZC}$ bacterium in its vector.

In summary, the results of studies reported here clearly indicate that the distribution of ' $\mathrm{Ca}$. L. solanacearum' is much more widespread than previously described. These results also substantiate that the bacteria associated with ZC and PY, ' $C a$. L. solanacearum' and ' $C a$. L. psyllaurous', respectively, are very closely related and cannot be distinguished effectively using the existing PCR assays. With the sequencing of the ' $C a$. L. solanacearum' genome nearly complete $(\mathrm{H}$. Lin, unpublished data), it would be useful to compare the ' $C a$. L. solanacearum' genome with that of ' $\mathrm{Ca}$. L. psyllaurous' at some future date. These types of studies may allow for virulence differences to be determined between the two putative pathotypes and may also reveal DNA sequences that can used to develop PCR primers capable of distinguishing between the two pathogens, 
something that would be useful in future epidemiological studies. Additionally, this study provides evidence that multiplex screening can eliminate false negatives attributable to poor DNA template quality, and that the newly designed $\beta$-tubulin primers may prove useful in screening numerous solanaceous hosts in the future.

\section{ACKNOWLEDGMENTS}

We gratefully acknowledge the financial support for this research obtained from the Texas Department of Agriculture through Texas AgriLife Research, Frito-Lay, Inc., CSS Farms, Black Gold Farms, Kirshenmann Farms, Western Potato Co., and the U.S. Potato Board. We also acknowledge Roberta Sherman, Nolan Anderson, Dean Peterson, Russell Benz, Bonnie Seaberg, Vannessa Vaughn, and Kristina Twigg for technical assistance; and Curt Doetkott for the technical assistance with statistical analyses.

\section{LITERATURE CITED}

1. Abad, J. A., Bandla, M., French-Monar, R. D., Liefting, L. W., and Clover, G. R. G. 2009. First report of the detection of 'Candidatus Liberibacter' species in zebra chip diseaseinfected potato plants in the United States. Plant Dis. 93:108.

2. Allison, P. D. 1999. Logistic Regression Using the SAS System: Theory and Application. SAS Institute Inc., Cary, NC.

3. Bové, J. M. 2006. Huanglongbing: A destructive, newly-emerging, century-old disease of citrus. J. Plant Pathol. 88:7-37.

4. Cranshaw, W. S. 2001. Diseases caused by insect toxin. Pages 73-74 in: Compendium of Potato Diseases. W. R. Stevenson, R. Loria, G. D. Franc, and D. P. Weingartner, eds. American Phytopathological Society, St. Paul, MN.

5. Crosslin, J. M., and Bester, G. 2009. First report of 'Candidatus Liberibacter psyllaurous' in zebra chip symptomatic potatoes from California. Plant Dis. 93:551.

6. Crosslin, J. M., and Munyaneza, J. E. 2009. Evidence that the zebra chip disease and the putative causal agent can be maintained in potatoes by grafting and in vitro. Am. J. Pot. Res. 86:183-187.

7. Crosslin, J. M., Vandemark, G. J., and Munyaneza, J. E. 2006. Development of a real-time, quantitative PCR for detection of the Columbia Basin potato purple top phytoplasma in plants and beet leafhoppers. Plant Dis. 90:663-667.

8. Deng, S., and Hiruki, C. 1991. Genetic relatedness between two nonculturable mycoplasmalike organisms revealed by nucleic acid hybridization and polymerase chain reaction. Phytopathology 81:1475-1479.

9. Duan, Y., Zhou, L., Hall, D. G., Li, W., Doddapaneni, H., Lin, H., Liu, L., Gabriel, D. W., Vahling, C. M., Williams, K., Dickerman, A., and Gottwald, T. 2009. Complete genome sequence of citrus huanglongbing bacterium, 'Candidatus Liberibacter asiaticus' obtained through metagenomics. Mol. Plant-Microbe Interact. 22:1011-1020.

10. Hansen, A. K., Jeong, G., Paine, T. D., and Stoughamer, R. 2007. Frequency of secondary symbiont infection in an invasive psyllid relates to parasitism pressure on a geographic scale in California. Appl. Environ. Microbiol. 73:7531-7535

11. Hansen, A. K., Trumble, J. T., Stouthamer, R., and Paine, T. D. 2008. A new Huanglongbing (HLB) species, "Candidatus Liberibacter psyllaurous", found to infect tomato and potato, is vectored by the psyllid Bactericerca cockerelli (Sulc). Appl. Environ. Microbiol. 74:58625865.

12. Henne, D., Workneh, F., Gudmestad, N., and Rush, C. 2009. Role of "Candidatus Liberibac- ter"-infected seed tubers in epidemiology of potato zebra chip. (Abstr.) Phytopathology 99:S52.

13. Henne, D. C., Workneh, F., and Rush, C. M. 2009. Potato psyllid (Bactericera cockerelli) dispersal and effects on potato yields. Proc. Annu. Meet. Southwestern Branch Entomol. Soc. Am. 57th. Stillwater, OK

14. Jagoueix, S., Bové, J. M., and Garnier, M. 1996. PCR Detection of the two 'Candidatus liberibacter' species associated with greening disease of citrus. Mol. Cell. Probes 10:43-50.

15. Kumar, S., Tamura, K., and Nei, M. 2004. MEGA3: Integrated software for molecular evolutionary genetics analysis and sequence alignment. Brief. Bioinform. 5:150-163.

16. Lee, I. M., Bottner, K. D., Secor, G. A., and Rivera-Varas, V. 2006. 'Candidatus Phytoplasma americanum', a phytoplasma associated with a potato purple top wilt disease complex. Int. J. Syst. Evol. Microbiol. 56:15931597.

17. Li, W., Abad, J. A., French-Monar, R. D., Rascoe, J., Wen, A., Gudmestad, N. C., Secor, G. A., Lee, I. M., Duan, Y. P., and Levy, L. 2009. Multiplex real-time PCR for detection, identification and quantification of 'Candidatus Liberibacter solanacearum' in potato plants with zebra chip. J. Microbiol. Methods 78:59-65.

18. Li, W., Hartung, J. S., and Levy, L. 2006. Quantitative real-time PCR for detection and identification of 'Candidatus Liberibacter' species associated with citrus huanglongbing. J. Microbiol. Methods 66:104-115.

19. Liefting, L. W., Perez-Egusquiza, Z. C., Clover, G. R. G., and Anderson, J. A. D. 2008. A new 'Candidatus Liberibacter' species in Solanum tuberosum in New Zealand. Plant Dis. 92:1474.

20. Liefting, L. W., Sutherland, P. W., Ward, L. I., Paice, K. L., Weir, B. S., and Clover, G. R. G. 2009. A new 'Candidatus Liberibacter' species associated with diseases of solanaceous crops. Plant Dis. 93:208-214.

21. Liefting, L. W., Ward, L. I., Shiller, J. B., and Clover, G. R. G. 2008. A New 'Candidatus Liberibacter' species in Solanum betaceum (Tamarillo) and Physalis peruviana (Cape gooseberry) in New Zealand. Plant Dis. 92:1588.

22. Liefting, L. W., Weir, B. S., Pennycook, S. R., and Clover, G. R. G. 2009. 'Candidatus Liberibacter solanacearum', a liberibacter associated with plants in the family Solanaceae. Int. J. Syst. Evol. Microbiol. 59:2274-2276.

23. Lin, H., Doddapaneni, H., Munyaneza, J. E., Civerolo, E. L., Sengoda, V. G., Buchman, J. L., and Stenger, D. C. 2009. Molecular characterization and phylogenetic analysis of $16 \mathrm{~S}$ rRNA from a new 'Liberibacter' strain associated with zebra chip disease of potato (Solanum tuberosum L.) and the potato psyllid (Bactericera cockerelli Sulc). J. Plant Pathol. 91:215-219.

24. Lindner, K., and Haase, N. U. 2008. Potato stolbur phytoplasma induced disease of potatoes grown in Romania - II. Low molecular weight carbohydrates. Pages 595-596 in: Proc. Trienn. Conf. Eur. Assoc. Potato Res. 17th. Brasov, Romania.

25. Lindner, K, Roman, M, Haase, N. U., and Maixner, M. 2008. Phytoplasma and Zebra chip. Pages 593-594 in: Proc. Trienn. Conf. Eur. Assoc. Potato Res. 17th. Brasov, Romania.

26. Lorenz, K.-H., Schneider, B., Ahrens, U., and Seemüller, E. 1995. Detection of the apple proliferation and pear decline phytoplasmas by PCR amplification of ribosomal and nonribosomal DNA. Phytopathology 85:771-776.

27. Munyaneza, J. E., Buchman, J. L., Upton, J. E., Goolsby, J. A., Crosslin, J. M., Bester, G., Miles, G. P., and Sengoda, V. G. 2008. Impact of different potato psyllid populations on zebra chip disease incidence, severity, and potato yield. Subtrop. Plant Sci. 60:27-37.

28. Munyaneza, J. E., Crosslin, J. M., and Upton, J. E. 2006. The beet leafhopper (Hemiptera: Cicadellidae) transmits the Columbia Basin potato purple top phytoplasma to potatoes, beets, and weeds. J. Econ. Entomol. 99:268272.

29. Munyaneza, J. E., Crosslin, J. M., and Upton, J. E. 2007. Association of Bactericera cockerelli (Homoptera: Psyllidae) with "Zebra chip", a new potato disease in Southwestern United States and Mexico. J. Econ. Entomol. 100:656-663.

30. Munyaneza, J. E., Goolsby, J. A., Crosslin, J. M., and Upton, J. E. 2007. Further evidence that zebra chip potato disease in the Lower Rio Grande Valley of Texas is associated with Bactericera cockerelli. Subtrop. Plant Sci. 59:30-37.

31. Munyaneza, J. E., Sengoda, V. G., Crosslin, J. M., De la Rosa-Lozano, G., and Sanchez, A. 2009. First report of 'Candidatus Liberibacter psyllaurous' in potato tubers with zebra chip disease in Mexico. Plant Dis. 93:552.

32. Schneider, B., Seemüller, E., Smart, C. D., and Kirkpatrick, B. C. 1995. Phylogenetic classification of plant pathogenic mycoplasma-like organisms or phytoplasmas. Pages 369-380 in: Molecular and Diagnostic Procedures in Mycoplasmology. Vol. 1. S. Razin and J. G. Tully, eds. Academic Press, San Diego, CA.

33. Secor, G. A., Lee, I.-M., Bottner, K. D., Rivera-Varas, V., and Gudmestad, N. C. 2006 First report of a defect of processing potatoes in Texas and Nebraska associated with a new phytoplasma. Plant Dis. 90:377.

34. Secor, G. A., Rivera, V. V., Abad, J. A., Lee, IM., Clover, G. R. G., Liefting, L. W., Li, X., and De Boer, S. H. 2009. Association of 'Candidatus Liberibacter solanacearum' with zebr chip disease of potato established by graft and psyllid transmission, electron microscopy, and PCR. Plant Dis. 93:574-583.

35. Slack, S. A. 2001. Aster yellows diseases. Pages 56-57 in: Compendium of Potato Diseases. W. R. Stevenson, R. Loria, G. D. Franc, and D. P. Weingartner, eds. American Phytopathological Society, St. Paul, MN.

36. Slack, S. A. 2001. Potato leafroll virus. Pages 63-64 in: Compendium of Potato Diseases. W. R. Stevenson, R. Loria, G. D. Franc, and D. P. Weingartner, eds. American Phytopathological Society, St. Paul, MN.

37. Smith, W. L., Jr., and Wilson, J. B. 1978 Purple top wilt. Page 51 in: Market Diseases of Potatoes. U.S. Dep. Agric. Agric. Res. Serv. Agric. Handb. No. 479

38. Subandiyah, S., Nokoh, N., Tsuyumu, S., Somowiyarjo, S., and Fukatsu, T. 2000. Complex endosymbiotic microbiota of the citrus psyllid Diaphorina citri (Homoptera: Psylliodea). Zoolog. Sci. 17:983-989.

39. Teixeira, D. C., Saillard, C., Couture, C., Martins, E. C., Wulff, N. A., EveillardJagoueix, S., Yamamoto, P. T., Ayres, A. J., and Bové, J. M. 2008. Distribution and quantification of 'Candidatus Liberibacter americanus', agent of huanglongbing disease of citrus in São Paulo State, Brazil, in leaves of an infected sweet orange tree as determined by PCR. Mol. Cell. Probes 22:139-150.

40. Teixeira, D. C., Saillard, C., Eveillard, S., Danet, J. L., da Costa, P. I., Ayres, A. J., and Bové, J. M. 2005. 'Candidatus Liberibacter americanus' associated with citrus huanglongbing (greening disease) in Sao Paulo State, Brazil. Int. J. Syst. Evol. Microbiol. 55:18571862.

41. Wang, B., Liu, J., Tian, Z., Song, B., and Xie, C. 2005. Monitoring the expression patterns of potato genes associated with quantitative resistance to late blight during Phytophthora infestans infection using cDNA microarrays. Plant Sci. 169:1155-1167. 